\title{
THE FLOATING CHARGE IN CANADA
}

RODERICK J. WOOD*

This article examines the evolution of the floating charge in England and Canada, and predicts its demise as a conceptually discrete security device upon the enactment of personal property security legislation in the provinces. However, the author contends that a study of the floating charge can aid our understanding of the economic and historical processes that shaped the judicial attitude towards the security idea and explains how this will be of continuing relevance following the implementation of a personal property security regime in Alberta.

\section{TABLE OF CONTENTS}

I. INTRODUCTION

II. NURTURE AND NATURE OF THE FLOATING CHARGE

III. FIXED OR FLOATING? ................... 195

A. THE IMPLIED LICENCE CASES. ............. 196

B. THE ASSIGNMENT OF BOOK DEBT CASES . . ... 196

C. THE RECENT CASES . .................... 198

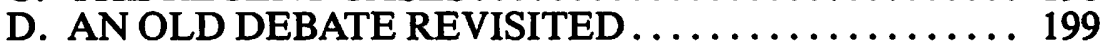

E. FUTURE IMPLICATIONS $\ldots \ldots \ldots \ldots \ldots \ldots \ldots \ldots \ldots$

IV. CRYSTALLIZATION ....................... 204

A. THE TRADITIONAL EVENTS OF

CRYSTALLIZATION..................... 204

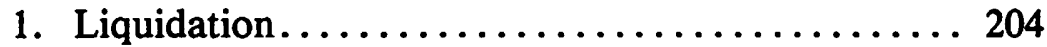

2. Ceasing To Do Business................ 205

3. Appointment of a Receiver ............... 205

4. Enforcing the Security.................. 205

B. AUTOMATIC CRYSTALLIZATION........... 206

V. RESOLUTION OF PRIORITY DISPUTES .......... 208

A. FLOATING CHARGE v. EXECUTION CREDITORS. 208

B. FLOATING CHARGE v. FIXED SECURITY

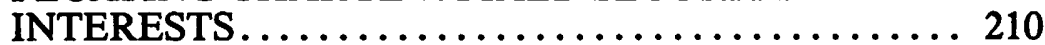

C. RESTRICTIVE PROVISIONS AND

CONSTRUCTIVE NOTICE ............... 211

D. NON-REGISTRATION OF SUBSEQUENT

MORTGAGES AND CONDITIONAL SALES ...... 212

E. FLOATING CHARGE v. FLOATING CHARGE ..... 212

F. FLOATING CHARGE v. STATUTORY LIENS . . . . . . 214

VI. A CANADIAN VERSION OF THE FLOATING

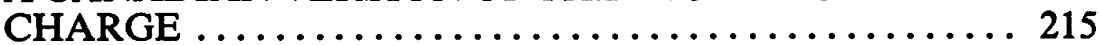

VII. THE EFFECT OF A PERSONAL PROPERTY

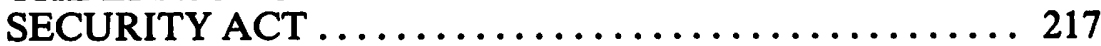

VIII. THE FLOATING CHARGE AS A FRAUDULENT

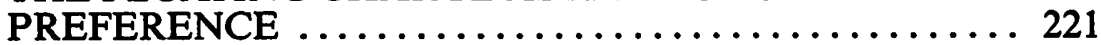

IX. CONCLUSION ........................ 223

- Assistant Professor of Law, University of Alberta, Faculty of Law. 
[VOL. XXVII, NO. 2

\section{INTRODUCTION}

It should not be too long before the floating charge in Canada is nothing more than a quaint historical artifact. The enactment of modern personal property security legislation by the provinces will make it unnecessary to know anything at all about this security device. It may therefore occur to the reader that the writing of an essay on the floating charge demonstrates a curious inability to let go of the past. No doubt this is partly true. The floating charge seems to produce a perverse fascination and hold over those who have had to struggle through its doctrinal intricacies. Even so, it is clear that the floating charge will not disappear immediately. Financial institutions will, for a time, continue to use old forms of security documents that purport to create a floating charge together with the restrictive and permissive clauses that are conventionally associated with the floating charge. It will be necessary to reconceptualize these provisions in light of the operation of the new personal property security regime, and I shall discuss the problems that arise out of this translation. But, as I hope to demonstrate, a study of the floating charge is important primarily because it will aid in our understanding of the economic and historical processes that shaped the judicial attitude towards the function and limits of the security idea, and will suggest the direction of future lines of inquiry.

It has been frequently commented that the nineteenth century development of personal property security law in the United States and the United Kingdom took remarkably divergent paths. In America the courts never overcame their suspicion that a mortgage over stock-in-trade was a species of fraudulent conveyance. ${ }^{1}$ This led to the proliferation of a host of strange devices, such as the trust receipt, factor's lien and field warehouse, which were designed to permit the use of inventory as security. It was not until the 1950 's that the laws governing these security devices were synthesized into a unitary concept of security by Article 9 of the Uniform Commercial Code. In England the experience was vastly different. The courts were receptive to the idea of a charge on the entire undertaking of a company. ${ }^{2}$ What is less well appreciated is that the floating charge in Canada has evolved away from the English notion and has acquired its own distinctive character. I hope to shed some light on how and why this came about.

\section{NURTURE AND NATURE OF THE FLOATING CHARGE}

It is often said that the floating charge was an invention of the courts of equity. This statement needs to be qualified; in the first instance the idea of

1. See G. Gilmore, 1 Security Interests in Personal Property (1965) 39-47.

2. The reason for the great divide between English and American law remains unexplained. One hypothesis is that the acceptance of the floating charge in England reflects a difference in the types of cases that were litigated. In England many of the cases involved bonds and debentures that were marketed to the public. See, for example, Re Panama, New Zealand, and Australian Royal Mail Company (1870) 5 Ch. App. 318 and Re Florence Land and Public Works Co. (1878) 10 Ch.D. 530, both of which involved the issuance of debentures of f100 each to the public. English courts may have had greater sympathy towards the investors than American courts had towards banks and other financial institutions that attempted to obtain a mortgage over stock-in-trade. 
a generalized security interest covering a company's entire undertaking originated from financiers who drafted such agreements. When some of these companies failed it became necessary for the courts to decide whether these agreements were effective in granting real rights to the financier. The financier could claim that the agreement should be effective according to its terms, a powerful argument in a period where the rhetoric of freedom of contract held great sway. However, two objections could be raised against these security agreements. The first was the traditional attack on the transaction as a fraudulent conveyance. All transactions, whether by way of sale or mortgage, that were not accompanied by an actual change in possession were liable to be set aside as a fraudulent conveyance. ${ }^{3}$ By the middle of the 19th century this attack had lost much of its vigour, ${ }^{4}$ and disappeared entirely upon the passage of the first of the English registry statutes. ${ }^{5}$ The second objection was based on property law principles. Common law courts were reluctant to recognize a mortgage of future goods. A debtor's acquisition of new property was not sufficient to cause the security interest to attach to it: a new act of transfer was required. ${ }^{6}$ Seizure of the goods by the mortgagee was a sufficient new act, ${ }^{7}$ but until the time of seizure, the common law did not recognize any interest in the new property that could be asserted against third parties.

The landmark case of Holroyd v. Marshall ${ }^{8}$ cleared the way for the development of the floating charge. A debtor had mortgaged the machinery in his mill. The security agreement provided that all machinery fixed or placed about the mill should be subject to the mortgage. The equitable title to new machinery passed immediately upon the debtor's acquisition of it without any need for a new act of transfer. The mortgagee was thereby permitted to assert his claim to substituted equipment in priority to the claim of a judgment creditor who had seized it. The creation of a fixed equitable mortgage in after-acquired property was thereby sanctioned.

Eight years later the case of Re Panama, New Zealand, and Australian Royal Mail Co. ${ }^{9}$ came before the Court of Appeal in Chancery. A steamship company had issued debentures charging its "undertaking" to secure the amounts repayable under the debentures. It was held the word

3. Twyne's Case (1601) 3 Co. Rep. 80b, 76 E.R. 809; Meggot v. Mills (1697) I Ld. Raym. 286, 91 E.R. 1088.

4. Kidd v. Rawlinson (1800) 2 B. \& P. 59, 126 E.R. 1155; Lady Arundellv. Phipps(1804) 10 Ves. 139, 32 E.R. 797; and Martindale v. Booth (1832) 3 B. \& A. 498, 110 E.R. 180 chart the progressive erosion of this rule.

5. Bills of Sale Act, 1854, c. 36. And see Cookson v. Swire (1884) 9 A.C. 653 at $664-5$ per Blackburn J. in which the enactment of the registry statute was regarded as a mechanism that would eliminate the perjury, fighting and expense that arose during the course of a judicial proceeding to determine whether or not the transaction was a sham.

6. Lunn v. Thornton (1845) 1 C.B. 379, 135 E.R. 587 (C.P.); Cummings v. Morgan (1885) 12 U.C.Q.B. 565 (C.A.).

7. Congreve v. Evetts (1854) 10 Exch. 298, 156 E.R. 457; Hope v. Hayley (1856) 5 El. \& Bl. 830, 119 E.R. 690. For a historical review of these early cases see D. W. McLauchlan, "Securities over Future Goods" (1974) 7 V. U. W. L. Rev. 122 at 123-129. See also G. F. Curtis, "The Theory of the Floating Charge" (1941) 4 U. of T. L. J. 131.

8. (1862) 10 H.L.C. 191,11 E.R. 999.

9. Supra n.2. 
"undertaking" referred to all present and future property of the company and its use implied that the company was entitled to deal with the property in the ordinary course of its business until the moment it was wound up. This form of security device would later become known as a floating charge. ${ }^{10}$

No coherent doctrinal theory had yet been worked out. In the cases that followed, the task of the courts was two-fold. Most immediately they had to resolve the questions of priority that came before them. But as well, they had to develop some theory to explain the peculiar matrix of priority rules that had already begun to evolve. Several early cases were suggestive of a fixed equitable charge combined with a licence that allowed the company to operate in the ordinary course of its business." This notion was eventually scotched by Buckley L.J. in Evans v. Rival Granite Quarries, Ltd.:'12

A floating security is not a future security; it is a present security, which presently affects all the assets of the company expressed to be included in it. On the other hand, it is not a specific security; the holder cannot affirm that the assets are specifically mortgaged to him. The assets are mortgaged in such a way that the mortgagor can deal with them without the concurrence of the mortgagee. A floating security is not a specific mortgage of the assets, plus a licence to the mortgagor to dispose of them in the course of his business, but is a floating mortgage applying to every item comprised in the security, but not specifically affecting any item until some event occurs or some act on the part of the mortgagee is done which causes it to crystallize into a fixed security.

In place of the licence theory, the courts adopted the metaphor of a cloud-like charge hovering over the enterprise, ready to descend upon the occurrence of a crystallizing event. Though aesthetically pleasing, this metaphor could not explain the apparent paradox of an existing but unattached property interest. This task has since been taken up by writers who offer competing theories about this pre-crystallization state of existence. ${ }^{13} \mathrm{~A}$ recent effort is that of Professor Goode who employs the notion of a fund: ${ }^{14}$

In English law, a fund is considered to have an existence distinct from that of its components. The contents of the fund are constantly changing as assets are removed from the fund and new assets come into it, but the identity of the fund itself remains unchanged, in much the same way as the river Thames remains the river Thames despite the fact that the water in it is never the same from one minute to the next. . . . Hence the peculiarity of the floating charge is that, like an interest in a trust fund, it has immediate existence even prior to attachment.

10. Re Colonial Trusts Corp. (1879) $15 \mathrm{Ch}$. D. 465 at 472 is the first case in which the term is used.

11. Re Florence Land and Public Works Co. [1878] $10 \mathrm{Ch}$. D. 530 at 540-41; Wallace v. Evershed [1899] 1 Ch. 891 at 854; Driver v. Broad [1893] 1 Q.B. 744. And see R.R. Pennington, "The Genesis of the Floating Charge" (1960) 23 Mod. L. Rev. 630 at 644-46.

12. [1910] 2 K.B. 979 at 999.

13. See, for example, J. Farrar, "World Stagnation Puts the Floating Charge on Trial" (1980) 1 Co. Lawyer 83 at 83-7 (defeasible equitable interest created prior to crystallization); and M.H. McLelland, "Commentary" in Equity in Commercial Relations (1987) at 278 (contingent equitable interest). W.J. Gough, Company Charges (1978) at 73-4 denies that there is any proprietary interest prior to crystallization, but this contention is problematic because it runs counter to judicial statements to the effect that an uncrystallized charge is a present security, and fails to account for the effectiveness of a restrictive provision in an uncrystallized floating charge debenture over a purchaser with notice of the restrictive provision. See E. Ferran, "Floating Charges - The Nature of the Security" [1938] Cambridge L.J. 213 at 236-7. And see Canadian Imperial Bank of Commerce v. W.G. Fahlman Enterprises Ltd., unreported, 20 March 1989, Alta. C.A., 8803-0083-AC.

14. R. M. Goode, Legal Problems of Credit and Security (2nd ed., 1988) at 49. 
A floating charge is typically taken on all present and after-acquired property of the debtor, but this is not an essential attribute. The interest may be taken in only a particular class of assets, ${ }^{15}$ and the class need not encompass future assets. ${ }^{16}$ Because the floating charge does not immediately attach to any specific item, the company remains at liberty to deal with the assets until crystallization. Crystallization denotes its conversion from a floating charge to a fixed charge. Upon crystallization the debtor's power to manage the assets comes to an end and the security interest attaches to the specific items that then comprise the class of assets. Scattered here and there throughout the Canadian law reports one may find statements to the effect that crystallization converts the equitable interest into a legal interest." These are heretical statements: the accepted dogma is that it remains an equitable interest throughout. ${ }^{18}$

Early Canadian cases on the floating charge are for the most part unremarkable. In them one finds a wholesale acceptance of the English authorities. The major question of the day was whether the floating charge was required to be registered under the bills of sale legislation..$^{19}$ It was generally believed that English law and Canadian law governing the floating charge were the same.

\section{FIXED OR FLOATING?}

A fixed specific security interest may be taken in future goods. Holroyd v. Marshall ${ }^{20}$ is a case on point. How then does one distinguish a fixed charge from a floating charge? English courts have indicated that it will depend upon the degree of freedom given to the debtor to deal with the collateral in the course of its business. This was clearly expressed by Vaughan Williams L.J. in Re Yorkshire Woolcombers Association, Ltd.:21

I do not think that for a "specific security" you need have a security of a subject-matter which is then in existence. I mean by "then" at the time of the execution of the security; but what you do require to make a specific security is that the security whenever it has once come into existence, and been identified or appropriated as a security, shall never thereafter at the will of the mortgagor cease to be a security. If at the will of the mortgagor he can dispose of it and prevent its being any longer a security, although something else may be substituted more or less for it, that is not a "specific security".

15. Federated Cooperatives Ltd. v. Blesse [1981] 3 W.W.R. 514 (Sask. Dist. Ct.) (floating charge on all milk delivery cheques).

16. Re Bond Worth Ltd. [1979] 3 All E.R. 919 at 954.

17. See, for example, Sperry New Holland Division of Sperry Inc. v. Central Farm Supply (Rycroft) Ltd. (1982) 19 Alta. L.R. (2d) 247 at 254 (Q.B.); and Re Miksoo Aviation Ltd. [1981] 5 W.W.R. 639 at 641 (Sask. Q.B.).

18. Federal Business Development Bank v. Prince Albert Fashion Bin Ltd. [1983] 3 W.W.R. 464 at 468 (Sask. C.A.); Gordon MacKay \& Co. Ltd. v. Capital Trust Corp. Ltd. [1927] S.C.R. 374 at 385-6 (per Duff J.); Glendale (Atlantic) Ltd. v. Gentleman (1977) 76 D.L.R. (3d) 303 (N.S.C.A.); Daon Development Corp. v. National Trust Co. Ltd. (1982) 43 C.B.R. (N.S.) 210 at 215 (B.C.S.C.).

19. F. W. Wegenast, The Law of Canadian Companies (1931) at 659-70; V.E. Mitchell, Canadian Commercial Corporations (1916) at 1279-90.

20. Supra n. 8.

21. [1903] 2 Ch. 284 at 294. 
The authorization and freedom to deal with the assets need not be expressed in the security agreement - an implicit authorization will suffice. ${ }^{22}$ Nor will the mere labelling of the charge as "fixed" be sufficient if the court concludes that the debtor is free to dispose of the assets. ${ }^{23}$

No such consensus was achieved in Canada. The picture is a complex one, and can only be fully appreciated when several strands of cases are unravelled.

\section{A. THE IMPLIED LICENCE CASES}

Beginning with Dedrick v. Ashdown, ${ }^{24}$ an 1887 decision of the Supreme Court of Canada, a legion of Canadian cases recognized the possibility of a chattel mortgage over stock-in-trade coupled with an ongoing licence that allows the debtor to dispose of the stock-in-trade in the ordinary course of business until default. ${ }^{25}$ In none of these cases was the transaction characterized as a floating charge. Indeed, in several cases the two were contrasted as distinct security devices. ${ }^{26}$

These cases may be traced back to an old line of English bills of sale cases in which the court recognized a mortgage of stock-in-trade coupled with an implied licence. ${ }^{27}$ This development was short-lived in England: it withered and died with the passage of the Bills of Sale (1878) Amendment Act 1882, ${ }^{28}$ because its formal requirements made it virtually impossible for a debtor to grant a security interest in present and future stock-in-trade. ${ }^{29}$

The Canadian provinces never enacted a similar requirement. Shopkeepers regularly granted chattel mortgages on their stock-in-trade, and ranchers encumbered their cattle, all subject to an express or implied licence that permitted them to sell in the ordinary course of business. The English line of authority flourished in this more hospitable environment.

\section{B. THE ASSIGNMENT OF BOOK DEBT CASES}

Chartered banks often took security in the form of a general assignment of book debts. The Courts had no hesitation in accepting that such an assignment could take the form of a specific assignment or could take the form of a floating charge. But it was more difficult to articulate how to

22. Re Bond Worth Ltd., supra n. 16.

23. In Re Brightlife Ltd. [1987] 2 W.L.R. 197 (Ch. D.).

24. (1887) 15 S.C.R. 227.

25. See, for example, Graveley v. Springer (1898) 3 Terr. L.R. 120; J. I. Case Threshing Machine Co. v. Gouley [1914] 7 W.W.R. 584 (Sask. Dist. Ct.); Nourse v. Canadian Canners Ltd. [1935] O.R. 361 (C.A.); and Insurance and Discount Corporation Ltd. v. Motorville C.ar Sales [1953] O.R. 16 (H.C.). The implied licence idea was also extended to conditional sales contracts: see, for example, McRorie v. Seward (1910) 13 W.L.R. 522 (Sask. C.A.).

26. Meen v. Realty Development Co. Ltd. [1954] 1 D.L.R. 649 (Ont. C.A.); Re Zegalski [1973] 1 W.W.R. 728 (Man. Q.B.).

27. Taylor v. M'Keand (1880) 5 C.P.D. 358; National Mercantile Bank, Ltd. v. Hampson (1880) 5 Q.B.C. 177; Walker v. Clay (1880) 49 L.J.P.C. 560; Payne v. Fern (1881) 6 Q.B.D. 620.

28. 45 and 46 Vict. 61, s. 4.

29. See D. W. McLauchlan, supra n. 7 at 131-6. 
differentiate the two. The banking practice was the same. Both were conducted on a non-notification basis. The bank's customer collected the debts as they became due and deposited the proceeds into its bank account, and it was only upon default that the bank notified the debtors of the assignment. Most banks used a form of document that created an immediate transfer of book debts by way of security, and this was held to create a specific assignment. However, the Canadian Imperial Bank of Commerce used a document that contained the following clause: ${ }^{30}$

PROVIDED ALWAYS that until default by the undersigned in payment of all or any part of indebtedness and liability of the undersigned to the Bank, or until notice by the Bank to the undersigned to cease so doing . . . the undersigned may continue to collect, get in, and deal with said debts, accounts, claims, moneys and choses in action in the ordinary course of the business of the undersigned, but not otherwise.

The inclusion of this clause (which was not included in the documents used by the other banks) was enough to transform the assignment into a floating charge. But why did its inclusion make such a difference? If all banks permitted their customers to collect the debts, why should an express statement to this effect render the transaction a floating charge? An unconvincing, formalistic explanation was offered by the courts: the intention of the parties was to be collected from the instrument itself and not from the conduct of the parties. ${ }^{31}$ This is quite contrary to the approach taken in characterizing other commercial dealings: the court will not be bound by the labelling used by the parties, but will look to the substance of the transaction. ${ }^{32}$

This Canadian notion of a fixed charge on book debts wormed its way into the law of the United Kingdom where, until recently, it was assumed that a general assignment of book debts necessarily created a floating charge. ${ }^{33} \mathrm{~A}$ form of debenture which purported to create a fixed charge on book debts was introduced. The proceeds of the book debts were required to be deposited in the customer's bank account (though the customer would then be free to draw upon those monies in the ordinary course of business). This control was sufficient to deprive the customer of its freedom to manage such assets - a feature that would otherwise convert the transaction into a floating charge despite its being labelled a fixed

30. Reproduced in D.R. Johnson, "Accounts Receivable Financing in Canada: Nature of the Charge and Rights of Priority" (1981) 15 U.B.C.L.R. 87 at 125. This fountain of litigation abruptly dried up in 1976 when the Canadian Imperial Bank of Commerce abandoned their form of document in favour of one similar to the general assignment used by other banks.

31. See Evans, Coleman \& Evans Ltd. v. R.A. Nelson Construction Ltd. (1958) 16 D.L.R. 123 (B.C.C.A.); Lettner v. Pioneer Truck Equipment Ltd. (1964) 47 W.W.R. 343 (Man. C.A.).

32. Helby v. Matthews [1895] A.C. 471 (H.L.) (lease distinguished from a contract of sale); Ramsey v. Pioneer Machinery Company Ltd. (1981) 15 Alta. L.R. (2d) 140 (C.A.) (lease distinguished from conditional sales agreement); Personal Loan \& Finance Corp. v. Kennedy [1948] 1 W.W.R. 318 (Alta. Dist. Ct.) (chattel mortgage distinguished from conditional sales agreement); and Street v. Mountford [1985] 2 All E.R. 289 at 294 (H.L.) (lease distinguished from a licence of land).

33. The stage was set in the early 1970s when Barclays Bank began to use a debenture that purported to create a fixed charge on book debts. See R.M. Goode, supra n. 14 at 52-4. 
charge in the debenture. ${ }^{34}$ Although the Canadian cases were cited, the fundamental difference in reasoning was ignored. ${ }^{35}$ For example, in the Manitoba case of Robin Hood Flour Mills Ltd. v. Fuller Bakeries Ltd., Nitikman J. said: ${ }^{36}$

Even if the debtor used the accounts receivable collected for the purposes above set out [to pay wages of employees, suppliers' accounts and other expenses in the ordinary course of business] without these monies going into its bank account, whether with or without the acquiescence of the Bank, it did not change the character of the security from a specific to a floating charge.

Thus, a close reading of the Canadian cases reveals that two distinct devices are available: (1) a floating charge on book debts; and (2) a fixed and specific charge on book debts coupled with a licence that permits the customer to collect the debts free from the charge, and treat the proceeds as its own.

\section{THE RECENT CASES}

The parting of ways between the English and Canadian cases has never been explicitly recognized, though in 1987 the British Columbia Court of Appeal came close to doing so in $R$. in Right of British Columbia v. Federal Business Development Bank. ${ }^{37}$ Arcrite Light granted a debenture to the Federal Business Development Bank under the terms of which the bank was given a "fixed and specific mortgage and charge" on all its personal property including stock-in-trade and inventory. A further provision allowed Arcrite to continue to sell the inventory in the ordinary course of business until notified by the bank to cease doing so. A priority competition arose between the bank and the provincial Crown which had a statutory lien for unpaid taxes. The question was whether a fixed charge coupled with a licence would be recognized, or whether it would be characterized as a floating charge.

The majority held that the debenture created a floating charge. Dedrick v. Ashdown ${ }^{38}$ and the other implied licence cases were explained away on the basis that the disputes in those cases were between the security holder and a person who bought inventory from the debtor. ${ }^{39}$ The majority was apparently of the opinion that in this context it did not matter whether a floating charge theory or a licence theory was employed because in both cases an ordinary course purchaser would take free of the security

34. Siebe Gorman \& Co. Ltd. v. Barclays Bank Ltd. [1979] 2 Lloyd's Rep. 142 (Ch. D.); In Re Keenan Brothers Ltd. (1985) 5 I.L.R.M. 641 (S.C.); In Re Brightlife Ltd., supra n. 23. See also R.A. Pearce, "Fixed Charges over Book Debts" [1987] J.B.L. 18.

35. An exception is the Irish case of Re Armagh Shoes Ltd. [1982] N.I. 59 (Ch. D.) at 66-9 in which the difference between the English approach and the Canadian approach is discussed.

36. (1963) 40 D.L.R. (2d) 207 at 222-3 (Man. Q.B.). To the same effect see: Lettner v. Pioneer Truck Equipment Ltd. (1964) 47 W.W.R. 343 at 349 (Man. C.A.).

37. [1988] 1 W.W.R. 1 (B.C.C.A.).

38. Supran. 24.

39. Supra n. 37 at 37. 
interest. ${ }^{40}$ The majority was of the view that the earlier cases had, without reflection, adopted the language of a fixed security interest with an implied licence. Because this characterization was not critical to the outcome, this language was dismissed as a looseness of terminology. But in cases where the distinction between the two is relevant, the majority was adamant that the security ought to be viewed as floating rather than fixed.

It is hard to escape the conclusion that the majority was more interested in signalling a return to the English position for what they thought were reasons of sound policy than they were in fashioning a convincing restatement of the law. They do not adequately explain the Canadian assignment of book debts cases in which the transaction was characterized as a fixed charge despite the control of assets by the debtor. ${ }^{41}$ Moreover, Canadian cases do distinguish between a floating charge and a fixed charge with a licence, ${ }^{42}$ and several Alberta decisions have drawn this distinction in contexts where this characterization is central to the resolution of priorities. A good example is Canadian Imperial Bank of Commerce v. Westward Parts Services Ltd. ${ }^{43}$ The debtor granted a floating charge debenture to the bank, and sometime later granted a chattel mortgage which covered all inventory and which was therefore subject to an implied licence. The Court gave priority to the chattel mortgage because the security interest attached immediately upon the debtor's acquisition of the new assets, whereas the floating charge only attached later, upon crystallization. If the chattel mortgage had been viewed as a floating charge, the bank would have been entitled to priority. ${ }^{4} \mathrm{This}$ decision was subsequently endorsed by the Alberta Court of Appeal. as $^{4}$

\section{AN OLD DEBATE REVISITED}

The problem that the judges in $R$. in Right of British Columbia v. Federal Business Development Bank were grappling with is not a new one. By the end of the nineteenth century it came to be recognized that the invention of

40. This proposition is questionable. The licence under a fixed charge has been construed more narrowly than the dealing power under a floating charge in which all but extraordinary transactions are permitted. Compare Consolidated Finance Company Ltd. v. Alfke and Waldron's Used Car Lot (1960) 31 W.W.R. 497 (Alta. S.C.) (sale of five automobiles to another automobile dealer not within the implied licence) with $\operatorname{Re~Borax~Co.~[1901]~} 1 \mathrm{Ch} .326$ (C.A.) (sale of all its property other than certain investments within the trading power under a floating charge). An attempt to restrict the trading power under a floating charge will not generally succeed: at best the clause will be regarded as a restrictive provision and will protect the floating charge holder only if the third party has notice of it. See E. Ferran, supra n. 13 at 230-4.

41. Robin Hood Flour Mills Ltd. v. Fuller Bakeries Ltd., supra n. 36.

42. Meen v. Realty Development Co. Ltd., supra n. 26.

43. [1985] I W.W.R. 160 (Alta. Q.B.).

44. Northland Bank v. G.I.C. Industries Ltd. (1985) 36 Alta. L.R. (2d) 200 (Q.B.).

45. Toronto Dominion Bank v. Hayworth Equipment Sales Ltd. (1987) 49 Alta. L.R. (2d) 193 (C.A.). It should be noted that the chattel mortgage in this case did not contain a trust proceeds clause and it is therefore not possible to distinguish this case on the basis that a trust proceeds clause may amount to a sufficient control over the collateral so as to prevent the charge from acquiring a floating character. 
the floating charge had fundamentally changed the economic position of the general creditors of a business. ${ }^{46}$ An execution creditor obtained priority over a floating charge only if the execution was fully completed before crystallization of the charge ${ }^{47}$ In 1895 the unenviable position of the unsecured creditors was commented upon: ${ }^{48}$

\begin{abstract}
An execution creditor is very much like a dog with a bone, and he may well begin to growl, metaphorically speaking, at being meddled with by debenture-holders. The floating debenture permits the company to deal with the property charged in the ordinary course of the company's business. The company may sell it, or mortgage it, or charge it. Given this free hand, the company goes on and contracts debts, the unpaid creditor levies execution, and then the debenture-holders, who have been lurking in ambush all the time, start up like Roderick Dhu's 'plaided warriers arm'd for strife', and remorselessly say to the execution creditor, 'Hand over to me the fruits of your execution. That property is mine' This is a genuine grievance. Practically it means that creditors of a company which has issued debentures can never levy execution because when executions begin a company is water-logged, if not sinking.
\end{abstract}

To the nineteenth century mind the simple cure to this problem was knowledge. The establishment of a public registry would provide trade creditors with a means of discovering the existence of the debenture and therefore it would be "their own fault if they [went] on trusting a company without good evidence of its solvency." ${ }^{49}$ The great flaw in this thinking is that it assumes that unsecured creditors base their decisions to lend on the extent of unencumbered assets owned by the debtor. In reality, general creditors do not rely upon this information, because they have no assurance that the assets will not be encumbered in the future; instead, they rely upon the financial health of the business. ${ }^{50}$ Nonetheless, the apparent legislative compromise between secured and unsecured creditors which was attributed to the registry statutes likely stifled the impulse for judicial intervention on behalf of the unsecured creditors. ${ }^{\text {st }}$

46. E. Manson, "The Reform of Company Law" (1895) 11 L.Q.R. 346 at 352; E. Manson, "The Growth of the Debenture" (1897) 13 L.Q.R. 418. This discovery can be viewed as contributing to the decline of classical contract law and its attendant notion of freedom of contract which failed to adequately take the rights of third parties into account. See P. S. Atiyah, The Rise and Fall of Freedom of Contract (1979) at 693-7. See also R. in Right of B.C. v. F.B.D.B., supra n. 37 at 35-6 (per McLachlin J.A.).

47. Evans v. Rival Granite Quarries, Ltd., supra n. 12.

48. "Note" (1895) 11 L.Q.R. 215.

49. E. Manson, "The Growth of the Debenture", supra n. 46 at 424 . These sentiments are echoed in Davey \& Co. v. Williamson \& Sons [1898] 2Q.B. 199. The first English registration statute covering company charges was enacted in section 14 of the Companies Act 1900 . See generally, Gough, supra n. 13 at 208-10.

50. D. G. Baird, "Notice Filing and the Problem of Ostensible Ownership" (1983) 12 J. Legal Studies 53 at 60-2. This point was recognized by Buckley J. in Re Cardiff Workmen's Cottage Co., Ltd. [1906] 2 Ch. 627 at 630:

The person who is at any moment the unsecured creditor of the company is always exposed to the danger that the company may execute in favour of other creditors incumbrances upon its property, and unless he can attack those securities on the ground of fraudulent preference they prevail as against him. So long as the company is a going concern the creditor who has obtained no charge upon property necessarily runs the risk of dispositions made by the company by sale, mortgage, or otherwise. I am conscious that this view renders the section of the Act of 1900 which requires registration of incumbrances of much less value.

51. This tendency can still be detected today: see Re Brightlife supra n. 23 at 206 (intervention of Parliament makes it wholly inappropriate for courts to impose additional restrictive rules on grounds of public policy). 
The British Columbia Court of Appeal understood that if it recognized a fixed charge combined with a licence this would destroy even the limited priority given to execution creditors, as the debtor's assets would be subject to a fixed charge and the judgment enforcement measures of the execution creditor would fall outside of the licence granted to the debtor. Madam Justice McLachlin, for the majority, thought that this would run counter to prevailing commercial expectations: ${ }^{32}$

\begin{abstract}
It would be unfair and inconsistent to permit a debentureholder to grant to a debtor the right to carry on business while insulating him from the usual legal incidents of doing business, such as seizure and sale by creditors and liens incidental to the business imposed by statute. . . . Any other conclusion would be contrary to ordinary commercial expectations and detrimental to the public interest. Fletcher-Moulton L.J's characterization of such a result as "astonishing" is as appropriate today as it was in 1910. By a simple compact between debtor and creditor, the usual remedies of the law upon which those dealings with business persons rely - seizure, garnishment and liens - would be negated.
\end{abstract}

This is not an entirely convincing rationale. A financier may take a fixed security interest in non-circulating assets, such as equipment, and permit the debtor to use them in the course of its business, yet this does not render them subject to seizure by unsecured creditors. Moreover, fixed security in circulating assets is possible if the secured party sets up a system under which its consent is required prior to the disposition of the asset ${ }^{53}-\mathbf{a}$ system in fact used in the United States and known as the field warehouse..$^{54}$

Grant Gilmore found a more powerful rationale in early American law, which was far less accommodating to financiers who took security in stockin-trade and accounts. ${ }^{35}$ Under the rule in Benedict v. Ratner ${ }^{36}$ an assignment of accounts would be struck down unless the accounts financier exercised sufficient dominion over the assets. ${ }^{7}$ Gilmore concluded that this promoted monitoring by the secured party and that this benefited unsecured creditors: ${ }^{38}$

It is an observable fact of business life that a doomed enterprise, during the last few months before the final descent into "hopeless insolvency," typically succeeds in piling up a large amount of unsecured debt. All but the most demanding creditors are put off, the bills and invoices go unpaid, new sources of credit are explored and exploited. And, as the debt piles up, sales and receivables fall off. When the day of reckoning can no longer be staved off, the disaster is total.

...

52. Supra n. 37 at 38-9.

53. R. M. Goode, supra n. 14 at 17-8.

54. See G. Gilmore, supra n. 1 at 146. Canadian experimentation with this system has been limited: see R. J. Wood, "The Pledge of Documents of Title in Ontario" (1984) 9 C.B.L.J. 81 at $94-8$.

55. G. Gilmore, id. at $39-47$ and $250-61$.

56. 268 U.S. 353 (S.C.).

57. The control requirement was more strict under the Benedict rule than the current English test used to distinguish a fixed charge from a floating charge: under the Benedict rule nothing was to go directly into the assignor's bank account - cheques were to be endorsed and delivered to the assignee who might then re-remit the funds to the assignor's bank account. The English test merely requires that the proceeds be paid into the bank account (supra n. 34). Failure to pass the Benedict rule made the assignment void; failure to pass the English test merely meant that a floating charge rather than a fixed charge was created.

58. G. Gilmore, supra n. 1 at 259-61. 
It is clear that a lender who scrupulously adhered to these Benedict-inspired practices as all the professionals did - could not help but keep close watch over his debtor's affairs; the term that came into common use to describe the assignee's unremitting supervision of the assignor's enterprise was "policing."

$\ldots$

Thus the Benedict-style assignee knew from day to day the state of his debtor's business health. He would recognize - or at all events be in a position to recognize - the symptoms of the last fatal plunge toward bankruptcy. At that point he might be expected, in his own self-interest, to intervene: if there still seemed to be hope, he might undertake a salvage operation in cooperation with other creditors; if all hope had vanished, he would call his loan, which, in the usual case, would bring the debtor's operation to a halt. The assignee's self-interest in this context ran parallel with the interest of his debtor's other creditors. They benefited from the fact that a professional with a substantial stake in the enterprise was acting as their policeman. It is reasonable to assume that in many cases shaky enterprises were preserved as a result of a timely intervention and that in many others the final disastrous ballooning of the unsecured debt just before bankruptcy was prevented by the assignee's cutting off the source of essential working capital.

Historically, the judicial uneasiness with the notion of the floating charge has been with the distributional consequences between secured and unsecured creditors - the 'sweeping up' of all assets by debenture-holders leaving nothing for unsecured creditors. ${ }^{99}$ However, when one examines the rules that have emerged, it is the monitoring explanation that is more compelling, for it alone explains why the control of the assets insulates a fixed charge holder from execution creditors. The monitoring incentive behind the peculiar priority rules of the floating charge is not as strong as that in the United States where the invalidation of contravening transactions effectively forced financing patterns to include a policing aspect. In Anglo-Canadian law the inferior priority status of the floating charge will merely tend to promote a greater degree of monitoring. In fact, subordination to execution creditors does not figure prominently in this calculation. If a floating charge holder adopts more extensive monitoring practices, it is because of the risk of subordination to statutory lien holders and competing secured creditors. The floating charge holder in the vast majority of cases will be able to crystallize the charge before an execution creditor can fully complete execution. Indeed, the present rule may in fact produce a perverse monitoring incentive as the secured party may find it easier to monitor the initiation of judgment enforcement measures than to monitor the financial health of the debtor.

59. See F. H. Buckley, "The Bankruptcy Priority Puzzle" (1986) 72 Va. L. Rev. 1393 at 1405-6 and 1410-1 (adverse reaction may have been influenced by the outdated view that unsecured creditors have some interst in the assets of the company, or may be attributable to a judicial concern with the prejudice suffered by unsecured creditors during the lag between the devaluation of their bankruptcy claims and the time they comprehend this change and adjus: to it by increasing the cost of unsecured credit). 


\section{E. FUTURE IMPLICATIONS}

Until recently, the boundary between a fixed charge and a floating charge in Canada was determined according to a different technique of demarcation than that employed in the United Kingdom. In Canada, where a floating charge and a fixed charge combined with a licence were regarded as two distinct devices, the question was one of the intention of the parties, and the task of the judiciary was to create a fictitious intention in cases where the security document did not unequivocably designate which form of security was intended. In the United Kingdom, the question centered upon the degree of control that had to be exercised by the secured creditor in order to prevent the security interest from acquiring a floating character. What is remarkable is that this difference could remain submerged for 85 years.

We may hypothesize that this blind spot was the result of two competing but contradictory impulses. The first was to maintain a unified doctrinal position with the United Kingdom and the rest of the Commonwealth. English cases form the backbone of Canadian floating charge law. Even today, when one examines the structure of legal reasoning contained in many judgments, one discovers that English cases are set up as authoritative of the doctrine, and Canadian cases are offered merely as exemplifications. The second impulse was the need to find an interpretation that would explain and preserve the established Canadian notion of a fixed security interest coupled with a licence. This was accomplished by a selective reading of English authority. However, as later English textwriters and judges brought home the point that it is the degree of control and not intention that mattered, the Canadian compromise became untenable.

$R$. in Right of British Columbia v. Federal Business Development Bank therefore represents an abandonment of the Canadian position in favour of a reunification with English doctrine. In support of this shift, the matter of distributional fairness between secured and unsecured creditors was offered as justification. But this explanation has a hollow ring to it. For one thing, distributional concerns have never informed the English position, which treats the matter as a neutral property rule, and allows its distributional effect to be undercut by other doctrines, such as automatic crystallization. For another, the actual distributional effects of the rule are marginal. A much stronger rule, akin to the Benedict $\mathrm{v}$. Ratner rule, would be required in order to re-mould commercial practices. Furthermore, this realignment is purchased at a cost. In a dissenting opinion, Mr. Justice Lambert noted that the chartered banks are allowed to take a fixed security interest coupled with a licence by utilizing the section 178 Bank Act security. ${ }^{60}$ This security has priority over an earlier floating charge. Thus non-bank lenders, which provide an essential source of funds for businesses that are turned down by chartered banks, will be inhibited from obtaining effective security if the floating charge is the only available security device. 
There is every reason to doubt whether a reunification of doctrine is possible at all. The Canadian commercial environment differs substantially from that in the United Kingdom. These differences in financing patterns will over time again produce a uniquely Canadian variant of English doctrine, ${ }^{61}$ at least in the dwindling number of provinces that have yet to enact modern personal property security legislation.

\section{CRYSTALLIZATION}

If the floating charge had been conceived as a fixed security interest with a licence that permitted the debtor to operate in the ordinary course of its business, priority competitions would be governed by an agency analysis and questions would be determined by applying principles of actual and ostensible authority. Instead, the floating charge attracted a unique property analysis: the charge did not specifically attach to the debtor's assets until the occurrence of a crystallizing event. Crystallization therefore denotes both the end of the debtor's power to manage the assets and the conversion of the floating charge into a fixed charge which fastens upon the assets in specie.

The events that will trigger crystallization were initially supplied by the courts through the implication of terms (hereafter referred to as "the traditional events"). More recently a controversy has arisen regarding nontraditional events of crystallization expressly set out in the security agreement (hereafter referred to as "automatic crystallization events").

\section{A. THE TRADITIONAL EVENTS OF CRYSTALLIZATION}

\section{Liquidation}

A winding up of the corporation, whether voluntary or at the instance of creditors, causes the floating charge to crystallize. Upon filing an assignment in bankruptcy, the debtor "ceases to have any capacity to dispose of or otherwise deal with his property," ${ }^{32}$ and this will cause the charge to crystallize. ${ }^{33}$ Where the debtor is petitioned into bankruptcy, it may become necessary to determine whether it is the date of the filing of the petition or the date that the receiving order is made that will cause crystallization of

61. One can find an analogous departure in other areas of commercial law. For example, the requirement that a reasonable time for payment be given before the secured party enforce its security has developed in Canada to the point that it can no longer be regarded as simply an implied term in a demand loan. The Canadian law which began with Ronald Elwyn Lister Ltd. v. Dunlop Canada Ltd. (1982) 135 D.L.R. (3d) 1 (S.C.C.) has expanded so that it now covers the enforcement of security interests that secure term loans in a non-receivership context. See, for example, Roynat Ltd. v. Northern Meat Packers Ltd. (1986) 29 D.L.R. (4th) 139 (N.B.C.A.); Canada Trust Mortgage Co. v. 562498 Ontario Ltd. (1987) 62 O.R. (2d) 741 (H.C.J.). Compare the restrictive English version of the rule in Bank of Baroda v. Pannessar [1986] 3 All E.R. 751 (Ch. D.).

62. Bankruptcy Act, R.S.C. 1985, c. B-3, s. 71(2).

63. Irving A. Burton Ltd. v. Canadian Imperial Bank of Commerce (1982) 36 O.R. (2d) 703 (C.A.); Federal Business Development Bank v. Prince Albert Fashion Bin Ltd. [1983] 3 W.W.R. 464 at 473 (Sask. C.A.). This point is sometimes overlooked: see Davis v. Workers' Compensation Board (Alberta) [1980] 2 W.W.R. 349 (Alta. Q.B.). 
the charge. The tendency in other jurisdictions ${ }^{64}$ is to restrict the "deemed relation back" provision to the internal working of the insolvency legislation, but the position is less certain in Canada. ${ }^{65}$

\section{Ceasing To Do Business}

A floating charge will crystallize when the debtor ceases to carry on business. A sale of substantially the whole undertaking will therefore cause the charge to crystallize. ${ }^{60}$

\section{Appointment of a Receiver}

The most common event of crystallization is the appointment of a receiver. A number of Canadian cases held that notice of appointment or some other overt act on the part of the receiver (such as taking possession of the premises) was necessary to crystallize the charge,${ }^{67}$ but these cases have since been discredited: the charge crystallizes the moment the appointment becomes effective ${ }^{68}$ since it is at this point that the debtor is divested of its power to manage the assets. ${ }^{69}$ Increasingly, consultants and monitors are engaged as part of an informal work out (or soft receivership). ${ }^{70}$ Sometimes the monitor or consultant goes beyond a mere passive role and actively manages the business. It remains to be seen whether the Courts will hold that this will result in a crystallization of the charge.

\section{Enforcing The Security}

The floating charge will crystallize when the secured party proceeds to enforce the security, such as by taking possession of the assets. It has been suggested that the commencement of an action by the charge holder is also sufficient, ${ }^{11}$ but this has been questioned, since the debtor remains free in the interim to manage the business. ${ }^{72}$ The secured party cannot cause the floating charge to crystallize upon a portion of the assets and leave the

64. Stein v. Saywell [1969] A.L.R. 481.

65. Re Hillstead Ltd. (1980) 103 D.L.R. 347 (Ont. S.C.) (relation-back doctrine used to determine when trustee in bankruptcy obtains status for purposes of the Personal Property Security Act).

66. Re Mobile Electric Ltd. (1979) 29 C.B.R. (N.S.) 204 (Ont. S.C.).

67. See, for example, Bank of Montreal v. Woodtown Developments Ltd. (1979) 99 D.L.R. (3d) 739 (Ont. H.C.J.).

68. Alberta Paper Co. v. Metropolitan Graphic Ltd. (1983) 28 Alta. L.R. (2d) 52 (Q.B.); Coopers \& Lybrand Ltd. v. National Caterers Ltd. (1982) 47 C.B.R. (N.S.) 57 (B.C.S.C.); MacKay \& Hughes (1973) Ltd. v. Martin Potatoes Inc. (1984) 9 D.L.R. (4th) 439 (Ont. C.A.).

69. Business Corporations Act, S.A. 1981, c. B-15, s. 91.

70. J. S. Kelly et al., Lending and Recovery: The Benefits and Pitfalls of Consulting Engagements (1985).

71. Industrial Development Bank v. Valley Dairy Ltd. [1953] 1 D.L.R. 788 (Ont. H.C.).

72. Devlin v. Hean (1982) 41 B.C.L.R. 206 (S.C.). See also F. Bennett, Receiverships (1985) at 47-8. 
company to carry on with the remainder ${ }^{73}$ unless this is specifically contemplated in the security agreement. ${ }^{74}$

\section{B. AUTOMATIC CRYSTALLIZATION}

The occurrence of an event of default will not of itself cause a floating charge to crystallize. Debentures typically provide that the security becomes "enforceable" upon default, but this is not the same as providing that the floating charge crystallizes upon default. Rather, it indicates that the secured party may elect to take steps, such as appointing a receiver, which will have the effect of crystallizing the charge. ${ }^{75}$

The security agreement may go further and provide that the floating charge crystallizes upon the occurrence of a particular event of default or upon notice being given to the debtor. Over the last 15 years Commonwealth cases have given effect to such clauses. ${ }^{7}$ It has been a well-kept secret that Canadian courts, at a much earlier date, gave effect to automatic crystallization provisions. In 1934 the Ontario Court of Appeal considered the matter in Great Lakes Petroleum v. Border Cities Oil Limited. ${ }^{n}$ A general assignment of book debts, which was held to create a floating charge, provided that until default or notice to the debtor to cease so doing, the debtor was entitled to collect the accounts in the ordinary course of business. The court held that either default or notice was sufficient to crystallize the charge. A similar view has been taken in Manitoba, ${ }^{78}$ Saskatchewan, ${ }^{79}$ and New Brunswick ${ }^{80}$ Of course, the circumstances causing the charge to automatically crystallize must be determined by reference to the debenture itself. If the security agreement provides that the debtor remains free to carry on business until default and notice to cease, ${ }^{81}$ then both conditions must be satisfied. If the obligation is in the form of a demand loan and the security agreement provides that the charge crystallizes upon default, then the charge will not crystallize until the demand is made and the debtor is unable to satisfy it ${ }^{82}$ It is not the demand but the failure to satisfy it within a reasonable time that will trigger crystallization. Canadian courts are willing to hold this reasonable time to

73. The Queen in Right of British Columbia v. Consolidated Churchill Copper Corporation Lid. [1978] 5 W.W.R. 652 (B.C.S.C.).

74. R. M. Goode, supra n. 14, at 41-2.

75. Toronto Dominion Bank v. Ram Interim Financing Ltd. (1984) 38 Alta. L.R. (2d) 208 (Q.B.); Re Obie Pty. Ltd. [1984] 1 Qd. R. 371 (S.C.); Re Bismarck Australia Pty. Ltd. [1981] V.R. 527 (S.C.).

76. Re Manurewa Transport Ltd. [1971] N.Z.L.R. 909 (S.C.); Deputy Commissioner of Taxation v. Horsburgh [1983] 2 V.R. 591 (S.C.); Re Woodroffes (Musical Instruments) Lrd. [1985] 2 All E.R. 908 (Ch. D.); Re Brightlife Lid., supra n. 23.

77. [1934] 2 D.L.R. 742.

78. Lettner v. Pioneer Truck Equipment Ltd. (1964) 47 W.W.R. 343 (Man. C.A.).

79. Re Surburban Industries Ltd. (1971) 15 C.B.R. (N.S.) 235 (Sask. Q.B.).

80. Pierce v. Marks-Sartain Ltd. (1977) 18 N.B.R. (2d) 40 (N.B. Co. Ct.).

81. Federated Co-operatives Ltd. v. Blesse, supra n. 15.

82. Canadian Imperial Bank of Commerce v. Sitarenios [1976] 73 D.L.R. (3d) 663 (Ont. C.A.). 
be several days $s^{83}$ with the result that the charge may not automatically crystallize until several days after the demand for payment is made.

The hostility attributed to Canadian courts regarding automatic crystallization provisions can be traced to the comments of Berger J. in The Queen in Right of British Columbia v. Consolidated Churchill Copper Corp. ${ }^{84}$ who stated:

How is anyone to know the true state of affairs between the debenture-holder and the company unless there is an unequivocal act of intervention? How can it be said that the default by the company terminated its licence to carry on business when in fact it was allowed by Brameda to carry on business for three years thereafter? If the argument were sound, the debenture-holder would be able to arrange the affairs of the company in such a way as to render it immune from executions. The debenture-holder would have all the advantages of allowing the company to continue in business and all of the advantages of intervening at one and the same time, to the prejudice of all other creditors.

Later British Columbia cases $^{85}$ as well as cases from Alberta ${ }^{86}$ and Newfoundland ${ }^{87}$ have also taken a hostile attitude towards the use of such clauses.

The antipathy towards automatic crystallization provisions stems from the idea that crystallization should fulfill a notification function ${ }^{88}$ by informing third parties that the secured party has intervened. The parties who might benefit from such notice can be divided into two classes. The first are subsequent transferees (whether buyers or secured parties) who would otherwise take free of the floating charge. However, even if automatic crystallization provisions were upheld, agency principles could be invoked to protect these transferees. ${ }^{89}$ Unsecured creditors form the second category of claimants. The requirement of visible intervention would benefit them in two ways. First, it signals that any new extension of credit should be negotiated cautiously (for example, by obtaining an agreement that post-receivership debts will be repaid in full in priority to the secured party).$^{90}$ Second, it would eliminate some of the wasted expenses of unsecured creditors who initiate judgment enforcement proceedings not knowing it was futile to do so because the floating charge had already crystallized.

We may begin with the observation that a rejection of automatic crystallization clauses makes little sense unless the notion of a fixed charge

83. Ronald Elwyn Lister Ltd. v. Dunlop Canada Ltd., supra n. 61. The case has been subsequently applied in numerous Canadian decisions.

84. Supra n. 73 at 665-6.

85. Re Christensen [1977] 5 W.W.R. 640 (B.C.S.C.); The Queen in Right of British Columbia v. Lega Fabricating Ltd. (1981) 126 D.L.R. (3d) 148 (B.C.C.A.).

86. Re Caroma Enterprises Ltd. (1979) 108 D.L.R. (3d) 412 (Alta. Q.B.); Toronto Dominion Bank v. Ram Interim Financing Ltd., supra n. 75. But see contra Alberta Paper Co. v. Metropolitan Graphics Ltd. (1983) 24 B.L.R. 134 (Alta. Q.B.).

87. Re St. John's Heritage Foundation (1984) 50 Nfld. and P.E.I.R. 171 (Nfld. S.C.).

88. An analogous notification argument was rejected by Canadian cases which held that a floating charge crystallizes when the appointment of a receiver becomes operative, and not when the receiver takes possession of the collateral (see the cases cited in n. 68).

89. See the discussion in Goode, supra n. 14 at 90.

90. See Canadian General Electric Co. Ltd. v. Bank of British Columbia (1983) 52 C.B.R. (N.S.) 1 (Alta. C.A.); Re Ashk Development Corp. Ltd. (1988) 61 Alta. L.R. (2d) 375 (Q.B.). 
with a licence is also rejected. A fixed charge coupled with a licence immunizes the secured party from the claim of execution creditors without the complications of self-generating crystallization. Even apart from this, the benefit to unsecured creditors is marginal at best. There is no obligation placed on a secured party to crystallize its charge upon an event of default. New credit may continue to be extended by trade creditors during this postdefault period. Even without automatic crystallization, the secured party will usually be able to intervene before the unsecured creditors complete their executions. ${ }^{11}$ Nor is the wasted expenses argument compelling because an execution creditor always runs the risk that its efforts will be frustrated by the subsequent crystallization of a floating charge prior to completion of the execution process. In any case, a refusal to give effect to automatic crystallization provisions might simply create an incentive for the secured party to monitor the activities of the unsecured creditors rather than monitoring the debtor.

If any significant incentive for greater monitoring by the secured party is produced by a rule against automatic crystallization clauses, it will be attributable to the need to take active steps to crystallize in order to obtain priority over statutory liens which automatically come into existence. But this effect is becoming muted. Increasingly, legislation creating statutory liens and trusts is drafted so that the priority of the lien no longer is affected by time of crystallization of a competing floating charge..$^{22}$ If indeed a refusal to recognize automatic crystallization provisions is part of a strategy to promote a greater degree of monitoring on the part of the secured party, then it is a hopelessly weak response.

\section{RESOLUTION OF PRIORITY DISPUTES}

A security interest that arises prior to the execution of a security agreement creating a floating charge will be entitled to priority unless it runs afoul of provincial or federal registration requirements. ${ }^{93}$ More difficult questions arise when the competing interest arises after the security agreement is executed but before the floating charge crystallizes.

\section{A. FLOATING CHARGE v. EXECUTION CREDITORS}

An execution creditor obtains priority over a floating charge if the execution is completed before crystallization. There has been much litigation concerning the precise point when this occurs. In the case of a writ of execution, the process is complete upon sale even though the sheriff has not yet paid the proceeds over to the execution creditor. If crystallization occurs after seizure but before sale, the debenture holder will prevail. ${ }^{94}$

91. See R.C.C. Cuming, "Commercial Law - Floating Charges and Fixed Charges of Afteracquired Property: The Queen in the Right of British Columbia v. F.B.D.B." (1988) 67 Can. Bar Rev. 506 at 516-8; W. Gough "The Floating Charge: Traditional Themes and New Directions" in Equity and Commercial Relationships (1987) at 262-3.

92. See infra $\mathrm{n} .141$.

93. See, for example, Bills of Sale Act, R.S.A. 1980, c. B-5, s. 2(1); Banks and Banking Law Revision Act, R.S.C. 1985, c. B-1 s. 178(4).

94. Ontario Development Corp. v. Trustee of the Estate of I.C. Suatac Construction Ltd. (1976) 69 D.L.R. (3d) 353 (Ont. C.A.). 
In the case of a garnishment of a debt, the predominant view is that the issue of a garnishee summons (or order nisi) is not sufficient - the execution creditor will prevail only on payment out of court ${ }^{95}$ (or upon granting of an order absolute). ${ }^{96}$ In this regard English and Canadian law is substantially the same.

English Courts applied a property approach in determining these particular priority points. Priority was given to the first party to obtain a proprietary interest in the specific asset. The debenture holder obtains such an interest upon crystallization. The execution creditor obtains such an interest upon sale or payment out of court. Delivery of a writ of execution to the sheriff binds the goods, and service of the garnishee summons attaches the debt, but in England this is not regarded as creating any proprietary interest in the assets. ${ }^{97}$ Commentators in England ${ }^{98}$ and New Zealand ${ }^{99}$ have argued that an execution creditor should be considered to possess proprietary rights upon the binding of the writ or the attachment of the debtor. Obviously this would enhance the priority position of unsecured creditors. This would also have the effect of promoting more monitoring by the debenture holder, as there would be a real likelihood that an execution creditor might obtain priority. It would also eliminate the wasted expenses of an execution creditor who initiates execution proceedings only to find that they have been nullified by the crystallization of a floating charge.

The Canadian position is curious. Many Canadian judges have described the binding effect of the writ as a proprietary interest in the nature of a lien or charge..$^{100}$ Service of a garnishee summons is said to create an equitable charge. ${ }^{101}$ Some courts have gone so far as to hold that the garnishee summons constituted an assignment of the debt, ${ }^{102}$ but this view has since been abandoned. ${ }^{103}$ English decisions have been applied without thought to whether the underlying principles of Canadian debtorcreditor law might have taken on a local flavour. The Canadian position is

95. Recent cases include: Cooper \& Lybrand Ltd. v. National Caterers Ltd. (1982) 47 C.B.R. (N.S.) 57 (B.C.S.C.); Yorkshire Trust Co. v. 304231 Alberta Ltd. (1986) 46 Alta. L.R. (2d) 47 (Q.B.).

96. Industrial Development Bank v. Valley Dairy Ltd. [1953] 1 D.L.R. 788 (Ont. H.C.).

97. See W. J. Gough, supra n. 13 at 161-6.

98. D. M. Hare and D. Milman, "Debenture Holders and Judgment Creditors - Problems of Priority" [1982] L.M.C.L.Q. 57.

99. R. J. Canlan, "Priorities Between Execution Creditors and Floating Charges" (1983) 10 N.Z.U.L.R. 111 .

100. See Deering v. Gibbon (1907), 1 Alta. L.R. 7 (S.C.). See also the cases cited in C.R.B. Dunlop, Creditor-Debtor Law in Canada (1981) at 149. Similarly, a writ registered in a land titles system forms a lien and charge on the land: Andrekson v. Peerless Pipe \& Equipment (1971) Ltd. [1982] 6 W.W.R. 303 (B.C.C.A.). But an order appointing a sheriff receiver of auction proceeds does not create a proprietary interest: Structural Instrumentation Inc. v. Hayworth Truck \& Trailer Ltd. [1984] 6 W.W.R. 68 (Alta. C.A.).

101. Imperial Oil Ltd. v. Abilene Contracting Co. Ltd. (1966) 57 D.L.R. (2d) 572 (B.C.C.A.). No such interest is created in the case of a pre-judgment garnishment: Continental Bank of Canada v. Cranemaster Equipment Rentals Ltd. (1983) 146 D.L.R. (3d) 569 (Alta. C.A.).

102. Kare v. North West Packers Ltd. (1954) 14 W.W.R. 251 (Man. C.A.).

103. General Brake \& Clutch Service Ltd. v. W. A. Scott \& Sons Ltd. (1975) 59 D.L.R. (3d) 741 (Man. C.A.). 
therefore unstable. Logically, the courts must either abandon the view that the execution creditor obtains any proprietary interest until sale or payment out ${ }^{104}$ or else they must depart from the English choice of priority point and give the execution creditor priority if the binding of the property occurs before crystallization.

\section{B. FLOATING CHARGE v. FIXED SECURITY INTERESTS}

A subsequent fixed security interest that attaches before a floating charge crystallizes will generally be entitled to priority. Two different theories have been invoked to explain this result: the property theory and the implied authority (agency) theory. The property theory focuses upon the event of crystallization which marks the time that an equitable interest specifically attaches to the assets. Since attachment occurs only after the creation of the competing fixed interest, the fixed interest claims priority as it is first in time. The agency theory focuses upon the implied authority granted to the debtor to deal with the assets in the ordinary course of business. Courts have slipped from one theory to another with ease. In some cases it makes no difference which is applied. Suppose that the debtor company grants a chattel mortgage on a portion of its assets. Under the property theory the mortgagee's priority is explained on the basis that the interest of the mortgagee is first in time because it comes into existence before the floating charge crystallizes. ${ }^{105}$ Under the agency theory the explanation is that the mortgagee falls within the company's implied authority ${ }^{105}$ However, sometimes the results are not the same. For example, if a floating charge comes into competition with a subsequent assignment of specific accounts, a property theory would give priority to the first to give notice to the account-debtor. ${ }^{107}$ Yet courts have invoked the agency theory and given priority to the assignee of specific accounts because the floating charge impliedly authorized such dealings. ${ }^{108}$ In other contexts it is the property theory that predominates. If a floating charge contains a restrictive provision, this will modify the authority actually conferred upon the debtor. The dealing may be without actual or apparent authority, yet a competing claimant without notice will have priority under the property theory by virtue of its being first in time. The modern notion of a floating charge therefore encompasses both theories; it is not a matter of a choice between one or the other.

104. It seems that this process has already begun: in MacKay and Hughes (1973) Ltd. v. Martin Potatoes Inc. (1984) 9 D.L.R. (4th) 439 (Ont. C.A.) it was held that no equitable interest is created upon service of the garnishee order.

105. See, for example, Toronto Dominion Bank v. Hayworth Equipment Sales Ltd., supra n. 45.

106. See, for example, Dominion Iron \& Steel Co. v. Canadian Bank of Commerce [1928] 1 D.L.R. 809 (N.S.S.C.).

107. Dearle v. Hall (1828) 3 Russ. 1, 38 E.R. 475 (L.C.).

108. Re Ind, Coope \& Co., Limited [1911] 2 Ch. 223; Ward v. Royal Exchange Shipping Co. Ltd. (1888) 58 L.T. 174. 


\section{RESTRICTIVE PROVISIONS AND CONSTRUCTIVE NOTICE}

Knowledge of the existence of a floating charge will not deprive a buyer or mortgagee of priority, because such dealings fall within the implied authority given to the debtor. The buyer or mortgagee will be subordinate to the floating charge only if the sale or mortgage is of substantially all the assets. ${ }^{109}$ Even here the buyer or mortgagee may gain priority if it obtains the legal title for value and without notice ${ }^{10}$ or if the floating charge debenture contains a permissive provision or subordination clause."'

A secured party will of ten attempt to shore up the low priority status of the floating charge by including in the debenture a restrictive provision (or negative covenant) which cuts down the scope of the debtor's licence to deal with the assets. This will not be effective against a consensual third party claimant unless the third party has notice of the restriction. Union Bank of Halifax v. The Indian General Investment Trust ${ }^{112}$ is the leading Canadian case on this point. The traditional Canadian view is that registration of a security agreement does not constitute constructive notice of it. ${ }^{113}$ The English view is that registration is notice of the existence of the floating charge, but not of any restrictive provision. ${ }^{114}$ Recently courts in Ontario, 115 Nova Scotia ${ }^{116}$ and British Columbia ${ }^{117}$ have held that registration is constructive notice of a restrictive provision contained in a debenture. It remains to be seen whether this approach will find favour in other provinces. An adoption of this view would greatly enhance the priority position of a floating charge debenture containing a restrictive provision, as unauthorized transactions would be subordinate to the floating charge. As a result, crystallization becomes largely irrelevant in priority competitions with buyers and mortgagees. If a sale or mortgage falls outside the implied or express authority of the debtor, then the buyer or mortgagee can obtain priority only if a subordination agreement is negotiated with the holder of the floating charge or if the floating charge holder waives its security.

Suppliers who sell under conditional sales agreements will have priority over a floating charge regardless of their state of knowledge since they retain legal title and the floating charge only attaches to the buyer's limited proprietary interest. ${ }^{118}$ English courts developed a similar idea in respect of

109. Re Mobile Electric Ltd., supra, n. 66 (sale of undertaking); Acmetrack Ltd. v. Bank Canadian National (1985) 27 B.L.R. 319 (Ont. C.A.) (chattel mortgage covering all the assets of the business).

110. McAllister v. Forsyth (1887) 12 S.C.R. 1.

111. Savin Canada Inc. v. Protech Office Electronics Ltd. (1984) 8 D.L.R. (4th) 225 (B.C.C.A.).

112. (1908) 40 S.C.R. 510.

113. See J. S. Ziegel, "Registration Statutes and the Doctrine of Constructive Notice" (1985) 63 Can. Bar Rev. 629.

114. The English \& Scottish Mercantile Investment Co., Ltd. v. Brunton [1892] 2 Q.B. 700; Wilson v. Kelland [1910] $2 \mathrm{Ch} .306$.

115. Acmetrack Ltd. v. Bank Canadian National, supra n. 109.

116. Royal Bank of Canada v. Maple Ford Sales Ltd. (1984) 24 B.L.R. 166.

117. Lloyds Bank of Canada v. Lumberton Mills Ltd. (1989) 71 C.B.R. (N.S.) 1 (B.C.C.A.).

118. Liquid Carbonic Co., Ltd. v. Rountree [1924] I D.L.R. 1092 (Ont. C.A.). 
purchase-money loans, ${ }^{119}$ but no similar development can be found in Canadian law.

\section{NON-REGISTRATION OF SUBSEQUENT MORTGAGES AND CONDITIONAL SALES}

Non-registration of subsequent mortgages and conditional sales agreements will not generally result in a loss of priority to an uncrystallized charge. Registration legislation merely renders the un-registered mortgage or conditional sales agreement void against subsequent mortgagees. Although crystallization may occur subsequently, it is the execution of the security agreement creating the floating charge that is relevant for registration purposes. ${ }^{120} \mathrm{It}$ is only if the further advances are subsequently made during an unregistered interval that the floating charge will be considered a subsequent mortgage. ${ }^{121}$ It might be argued that even in the case of further advances, the unregistered subsequent mortgage or conditional sales agreement should be entitled to priority if it falls within the implied authority conferred upon the debtor or within an express permissive provision. However, the underlying assumption is that even if the transaction is permitted, the floating charge holder should have access to this information, which is accomplished by requiring registration. ${ }^{122}$

\section{E. FLOATING CHARGE v. FLOATING CHARGE}

The implied dealing power in a floating charge is sufficiently wide to permit the creation of a subsequent floating charge over part of the encumbered assets. ${ }^{123}$ It will not, however, permit the debtor to create a floating charge over the entire corpus of encumbered assets, ${ }^{124}$ unless there is a permissive provision to this effect in the earlier floating charge debenture. ${ }^{125}$ In the absence of an express or implied authorization, some other method must be invoked to resolve a priority dispute between two floating charges on the same assets. Canadian courts have held that order of crystallization cannot determine priorities because crystallization of one floating charge will cause a simultaneous crystallization of the other floating charge. ${ }^{26}$ The Saskatchewan Court of Appeal stated that a contrary rule would create "insurmountable difficulties in the business

119. Re Connolly Bros. Ltd. (No. 2) [1912] 2 Ch. 25. See also R. M. Goode, supra n. 14 at 55-7.

120. W. C. Fast Enterprises Ltd. v. All-Power Sports (1973) Ltd. (1981) 16 Alta. L.R. (2d) 47 (C.A.).

121. Liftow Ltd. v. Peat Marwick Ltd. (1983) 146 D.L.R. (3d) 116 (N.S.C.A.); Navistar Financial Corporation Canada Inc. v. Bank of Nova Scotia (1988) 59 Alta. L.R. (2d) 97 (C.A.).

122. Matsushita Electric of Canada Ltd. v. Central Trust Co. (1986) 73 N.S.R. (2d) 250 at 260 (S.C.).

123. Re Automatic Bottle Makers Ltd. [1926] Ch. 412.

124. Re Household Products Co. Ltd. (1981) 124 D.L.R. (3d) 325 (Ont. H.C.J.); Re Benjamin Cope \& Sons Ltd. [1914] 1 Ch. 800.

125. Savin Canada Inc. v. Protech Office Electronics Ltd., supra n. 111.

126. Re Household Products Co. Lid., supra n. 124; Northland Bank v. G.I.C. Industries Ltd. (1985) 29 B.L.R. 173 (Alta. Q.B.); Federal Business Development Bank v. Prince Albert Fashion Bin Ltd. [1983] 3 W.W.R. 464 (Sask. C.A.). 
world" and that "it should not be necessary for each of the debentureholder to have a receiver representing them in order to ensure that their claim to priority is upheld." ${ }^{27}$ The Court instead applied a first to register rule of priority. An English decision has taken the contrary view. ${ }^{128}$ The court was unwilling to imply a term that a bank's charge would automatically crystallize upon the crystallization of another charge since the bank might have been willing to grant an indemnity or even pay off the other debenture. Thus, in England it is possible that the later floating charge will have priority over an earlier floating charge so long as it is the first to crystallize. ${ }^{129}$

In Canada a first in time rule is applied, but the time of registration (rather than the time of execution) is used to determine priorities. This rule is inconsistent with the theory of the present registry system which, unlike the PPSA, does not directly link order of registration to priority. Registration merely has the negative effect of invalidating a security interest as against certain third parties. If this theory were applied, priority would be determined according to order of execution, and failure to register the earlier floating charge would cause its invalidation only if the subsequent floating charge was without notice.

This shift to a first to register rule represents a further judicial reevaluation of the theoretical function of a registry system. The purpose of a registry was originally seen as having two objects: $:^{130}$

[O]ne was to ensure notice of such mortgages being conveyed to purchasers, mortgagees, and creditors; the other, to provide for them some assurance that they were bona fide, and not made for any fraudulent purpose, so that they, especially creditors, might not be unnecessarily deterred from dealing with the goods comprised in them.

The registry statutes provided that an unregistered security interest was "void as against creditors". ${ }^{131}$ Because one of the objects was to give creditors some assurance that the transaction was not a sham, it did not matter whether the creditors impugning the transaction became creditors before or after the unregistered security interest was taken ${ }^{132}$ or whether they had notice. ${ }^{133}$

127. Federal Business Development Bank v. Prince Albert Fashion Bin Ltd., id. at 473.

128. Re Woodroffes (Musical Instruments) Ltd., supra n. 76. For a criticism of this view see: L.C. Chiaw, "The Crystallization of Floating Charges, Subordination Agreements and Priority Conflicts" (1986) L.M.C.L.Q. 519 at 527.

129. R. M. Goode, supra n. 14 at 87 suggests that the earlier floating charge will have priority even if a subsequent floating charge is the first to crystallize because the dealing power implied in a floating charge does not extend to the grant of a subsequent floating charge on the same assets. But this does not explain how it is that the earlier floating charge obtains priority since even an express restrictive provision does not operate unless the subsequent party has actual notice of it. The principle of constructive notice would in most cases ensure that the earlier floating charge would be entitled to priority; but as the second charge may have been taken before the first was registered (there is a 21 day grace period under the English Companies Act 1985, c. 6, s. 395), it would seem that time of crystallization will still be significant in some cases.

130. Fisken v. Rutherford (1860) 8 Gr. 9 at 30 .

131. See, for example, Bills of Sale Act, supra n. 93.

132. E.R.C. Clarkson v. McMaster \& Co. (1896) 25 S.C.R. 96; Graf v. Lingerell (1914) 6 W.W.R. 566 (Alta. S.C.).

133. Barron \& O'Brien, Chattel Mortgages and Bills of Sale (1897) at 282-3. This Canadian textbook cites American cases in support of the proposition that creditors need not be without notice of an unregistered chattel mortgage. 
Once the distrust of non-possessory security interests had passed, the notice function became the dominant theory. The purpose of the registry was no longer conceived as a means of weeding out fraudulent conveyances, but as a method of ensuring that subsequent parties did not rely upon the apparent ownership of goods in the debtor's possession. Several courts re-interpreted the legislation to mean that the unregistered security interest was void only against subsequent creditors ${ }^{134}$ without notice of the unregistered security interest. ${ }^{135}$ Next there developed the notion of constructive notice. The integrity of the registry would be enhanced if a positive obligation to search the registry were placed on third parties. ${ }^{136}$

Canadian cases have now moved beyond a notice theory when resolving a dispute between two floating charges. The registry is no longer conceived as a source of knowledge, but rather is treated as a source of priority in much the same way as accomplished in modern personal property security legislation. ${ }^{137}$

\section{F. FLOATING CHARGE v. STATUTORY LIENS}

Since 1897 English legislation has given preferred creditors (such as unpaid employees) priority over a floating charge debenture. ${ }^{138}$ Canadian provinces that based their corporations legislation upon the English Companies legislation tended to follow suit, but this model has been largely abandoned. ${ }^{139}$ Instead, Canadian courts use a property approach to resolve priorities. If the lien or trust comes into existence before crystallization, it will be entitled to priority; if crystallization precedes the creation of the lien, the secured party will win. ${ }^{140}$ This scheme can be modified if the legislation creating the lien contains a super-priority provision which gives it priority over existing property interests, ${ }^{138}$ and the modern tendency is to expressly provide for the priority status of the lien. ${ }^{141} \mathrm{~A}$ further complication arises out the scheme of distribution set out in section 136 of the Bankruptcy Act. ${ }^{142}$ If a debtor becomes bankrupt, the priority of the lien claimant will in most cases be determined by section 136, with the result

134. J.R. Auto Brokers Ltd. v. Hillcrest Auto Lease Ltd. (1968) 70 D.L.R. (2d) (Ont. H.C.); Hunfrey v. Hickey (1972) 25 D.L.R. (3d) 224 (Alta. C.A.).

135. Sperry New Holland v. Central Farm Supply (Rycroft) Ltd. (1982) 19 Alta. L.R. (2d) 247 (Q.B.).

136. Kozak v. Ford Motor Credit Co. of Canada Ltd. (1971) 18 D.L.R. (3d) 735 (Sask. C.A.); Acmetrack Ltd. v. Bank Canadian National, supra n. 109; Royal Bank of Canada v. Maple Ford Sales Ltd., supra n. 116; Henfrey v. G.H. Singh \& Sons Trucking Ltd. [1982] 2 W.W.R. 177 (B.C.S.C.) (registration of notice of intention of s. 178 Bank Act security constitutes constructive notice); Lloyds Bank of Canada v. Lumberton Mills Ltd., supra n. 117.

137. Personal Property Security Act, S.A. 1988, c. P-4.05, s. 35(1)(a).

138. Preferential Payments in Bankruptcy Amendment Act, 1897, c. 19 (U.K.).

139. See, for example, the Companies Act, R.S.A. 1980, c. C-20, s. 283(2)(b), now superceded by the Business Corporations Act, supra n. 69, which has no equivalent provisions.

140. Industrial Development Bank v. Valley Dairy Ltd., supra n. 96.

141. See, for example, Workers' Compensation Act, S.A. 1981, c. W-16, s. 126(2) as am. S.A. 1984, c. 68, s. 35 which gives the Board a charge having priority over all mortgages "whether legal or equitable in nature, whether absolute or not, whether specific or floating, whether crystallized or otherwise perfected or not and whenever created or to be created"'

142. Supra n. 62. 
that the lien claimant loses the priority that it would otherwise enjoy under provincial law. ${ }^{143}$ Furthermore, a secured creditor is permitted to invoke the bankruptcy process for the sole purpose of achieving this inversion of priorities. ${ }^{144}$

\section{A CANADIAN VERSION OF THE FLOATING CHARGE}

Although modern Canadian and English law of the floating charge share a common ancestry, they are now fundamentally different in conception. In Canada, the floating charge has acquired many of the attributes of a fixed security interest. In addition, the priority rules have moved steadily closer to the first to register rule that forms the backbone of personal property security legislation. By contrast, the floating charge in England has retained its floating character together with its relatively inferior priority status. British Columbia must be singled out as an exception to the Canadian trend as its courts have moved towards a re-adoption of the English notion.

In Canada, the widespread use of restrictive provisions combined with judicial acceptance of constructive notice of such provisions greatly diminishes the difference between a fixed and a floating charge since registration will ensure priority over subsequent prohibited transactions. A subsequent conditional sales agreement will nevertheless continue to enjoy priority because the charge only attaches to the limited interest of the buyer. ${ }^{145}$ The resolution of priorities between competing floating charges on the basis of a first to register rule moves even closer to the system of priorities contained in personal property security legislation: a first to register rule subject to a purchase-money priority..$^{146}$ Finally, the acceptance of a fixed security interest coupled with an express or implied licence renders suspect any argument that the inferior status of the floating charge is justified on policy grounds. ${ }^{147}$

143. Re Deloitte, Haskins \& Sells and Workers' Compensation Board (1985) 19 D.L.R. (4th) 577 (S.C.C.). Judicial opinion is divided on whether or not a deemed statutory trust will be subject to a similar inversion of priorities. See The Queen in Right of British Columbia v. Henfrey Sampson Belair Ltd. (1987) 40 D.L.R. (4th) 728 (B.C.C.A.); Re Clarkson Gordon Inc. and the Queen in Right of Manitoba (1987) 31 D.L.R. (4th) 701 (Man. C.A.) (deemed statutory trust not effective in altering scheme of distribution under s. 107); Re Phoenix Paper Products Ltd. (1983) 3 D.L.R. (4th) 617 (Ont. C.A.); Re Robinson, Little \& Co. Ltd. (1987) 67 C.B.R. (N.S.) 197 (Sask. Q.B.) (s. 107 not applicable because deemed trust falls within s. 47(a) of the Bankruptcy Act with the result that it does not form part of the divisible property). Alberta has enacted a deemed trust provision: see Employment Standards Code, S.A. 1988, c. E-10.2, s. 110.

144. Re Fresh Air Fireplaces of Canada Ltd. (1987) 62 C.B.R. (N.S.) 39 (Alta. Q.B.), affd. (1987) 65 C.B.R. (N.S.) 21 (Alta. C.A.); Bank of Montreal v. Scott Road Enterprises Ltd., unreported, 20 March 1989, B.C.C.A., CA008758. For a trenchant criticism of the strategic use of bankruptcy in order to effect change in the relative priorities in bankruptcy see T.H. Jackson, "Translating Assets and Liabilities to the Bankruptcy Forum" (1985) $14 \mathrm{~J}$. Legal Studies 73 at 74-5.

145. See the discussion, supra in Part V, C, of this article.

146. See the discussion, supra in Part V, E, of this article.

147. See the discussion, supra in Part III of this article. 
We may speculate that the English position was driven by the absence of an early development of the conditional sales agreement as an institutional security device. The recognition of an all-encompassing security interest in the debtor's undertaking produces a situational monopoly. ${ }^{14}$ The early English development of the law was directed towards breaking this monopoly. The courts first implied a very wide licence which permitted the company to grant mortgages of its property in priority to a floating charge. ${ }^{149}$ Debentures were subsequently redrafted with the inclusion of restrictive provisions which prohibited the creation of a subsequent charge ranking in priority or pari passu. The courts then thwarted this move by holding that registration of the debenture was not constructive notice of a restrictive provision, ${ }^{150}$ and this rule has been upheld even though the use of such provisions is now commonplace. ${ }^{151}$ A concern over a situational monopoly would also explain the courts' antipathy towards the idea of a fixed charge coupled with a licence, ${ }^{152}$ which permits ordinary course sales, but does not subordinate the security interest to subsequent financiers. Finally, in England one finds the development of a purchase-money priority for loans that has no counterpart in Canadian law. ${ }^{133}$ In Canada, the institutional use of conditional sales agreements seems to have been borrowed from the United States, and by the turn of the century it was common to find it used as a wholesale financing device. ${ }^{154}$

Recent cases from British Columbia have been greatly influenced by the question of distributional fairness between secured and unsecured creditors. ${ }^{135}$ Whether this is taken at face value, or reconceptualized as a concern over structuring financing patterns so as to promote the efficient monitoring of the enterprise, its impact has not been great. A more consistent approach would be to regard a fixed charge with a licence as a floating charge, to refuse to give effect to automatic crystallization clauses, and to

148. See T.H. Jackson and A.T. Kronman, "Secured Financing and Priorities Among Creditors" (1979) 88 Yale L.J. 1143 at 1167-75. (purchase-money priority blunts the situational monopoly that would otherwise be created by acceptance of an after-acquired property clause). The rule that a prior mortgagee cannot tack future advances to the mortgage in priority to intervening mortgagees of whom it has notice may also be viewed as a blunting of this situational monopoly. See Hopkinson v. Rolt (1861) 9 H.L. Cas. 514.

149. Wheatley v. Silkstone and Haigh Moor Coal Co. (1885) 29 Ch. D. 715 at 723-4 (floating charge security does not prevent the making of specific charges or specific alienation of property "because it would destroy the very object for which the money was borrowed, namely, the carrying on of the business of the company").

150. Supran. 112.

151. J.H. Farrar, "Floating Charges and Priorities" (1974) 38 Conv. 315 at 323-8.

152. See the discussion, supra in Part III of this article.

153. Supra n. 119.

154. As early as 1892 the Province of Ontario had enacted legislation which required registration of conditional sales agreements covering merchandise sold to a trader and which provided that an ordinary course buyer should take free of the conditional sales agreement whether or not it was registered. See 55 Vict., c. 27, ss. 4 and 5.

155. See the discussion of $R$. in Right of British Columbia v. Federal Business Development Bank, supra in Part III, C, of this article (fixed charge coupled with a licence to be considered a floating charge); and the discussion of The Queen in Right of British Columbia v. Consolidated Copper Corporation Ltd., supra in Part IV, B, of this article (hostility to automatic crystallization provisions). 
interpret the binding effect of an execution as having a proprietary effect so as to advance the point at which an execution creditor obtains priority. But in England ${ }^{156}$ and in provinces such as Alberta, ${ }^{157}$ the mix of rules that is adopted belies this concern.

\section{THE EFFECT OF A PERSONAL PROPERTY SECURITY ACT}

Ontario was the first province to enact personal property security legislation ${ }^{188}$ based upon Article 9 of the American Uniform Commercial Code. The migration of this idea has been westward - Manitoba ${ }^{139}$ in 1973, Saskatchewan ${ }^{160}$ in 1980, the Yukon ${ }^{161}$ in 1982, and Alberta ${ }^{162}$ in 1988. British Columbia ${ }^{163}$ is proposing to enact legislation substantially the same as the Alberta legislation.

The initial Ontario experience of integrating this new system with the notion of a floating charge was not a happy one. The floating charge was originally left outside of the scope of the PPSA,,$^{164}$ and was later brought half-way in by a "band-aid" amendment permitting, but not requiring, registration of a floating charge debenture in the PPSA registry. ${ }^{165}$ The maintenance of two distinct systems led to a baffling series of cases which attempted to work out solutions to difficult problems of scope and priority. ${ }^{166}$ There is really only one lesson to be learned from this: the floating charge debenture must be brought within the legislation. All other provinces that have enacted a PPSA have done so, and Ontario has decided recently to abort its experiment. ${ }^{167}$

The Canadian experience to date suggests the eventual abandonment of the floating charge debenture. Institutional lenders are introducing modernized forms of security agreements which adopt the new terminology of

156. A fixed charge coupled with a licence is considered a floating charge (See Re Yorkshire Woolcombers Association, Ltd., supra n. 21) but automatic crystallization provisions are permitted (see the cases cited supra n. 76).

157. A fixed charge coupled with a licence is permitted (see the cases cited supra n. 43-5), but automatic crystallization provisions are not effective to crystallize a floating charge (see the cases cited supra n. 86).

158. R.S.O. 1980, c. 375 (enacted in 1967 but not proclaimed in force until 1976). The Act has been replaced with an updated version: Personal Property Security Act, 1989, S.O. 1989, c. 16 (not yet proclaimed).

159. S.M. 1973 , c. 5/P. 35, as am.

160. S.S. $1979-80$, c. P-6.1, as am. S.S. $1980-81$, c. 72.

161. O.Y.T. 1980 (2d), c. 20.

162. S.A. 1988, c. P-4.05, coming into force October $1,1990$.

163. Draft Personal Property Security Act, British Columbia Ministry of Finance and Corporate Relations (April 1988).

164. Supra n. 158, s. 3(1)(c).

165. Section 66a, added to the PPSA by The Personal Property Security Amendment Act, S.O. 1981 , c. 2, s. 1 .

166. These problems are reviewed in Euroclean Canada Inc. v. Forest Glade Investments Ltd. (1985) 16 D.L.R. (4th) 289 (Ont. C.A.).

167. Personal Property Security Act, 1989, supra n. 158, s. 4. 
the PPSA. Already some of these agreements have acquired an institutional character. Banks commonly use a standard form security agreement called a "general security agreement" (or g.s.a.) which grants to the bank a security interest in all the debtor's present and after acquired personal property. Priorities are determined by an internal set of priority rules rather than through the application of legal and equitable property law principles. A general security agreement creates an immediate security interest the moment the debtor acquires rights in the personal property. ${ }^{168}$ There is nothing analogous to the inchoate pre-crystallization state of the floating charge: the security agreement is either in existence (i.e., it has attached to the collateral), or it is not. In competitions between two secured parties, priority will be governed by the first to register or perfect the security interest, ${ }^{169}$ unless some other special rule governs, such as the special priority given to purchase-money security interests. ${ }^{170}$ Buyers in the ordinary course of business will be entitled to priority, ${ }^{171}$ as will unsecured creditors who are actually paid by the debtor. ${ }^{172}$ If the unsecured creditor is not paid, the secured party will prevail unless it runs afoul of the registration requirements (in which case it is unperfected and consequently subordinate to seizing creditors and the trustee in bankruptcy). ${ }^{173}$ An execution creditor does not obtain priority by completing execution before the secured party appoints a receiver or otherwise intervenes since there is no concept equivalent to crystallization. ${ }^{174}$

Parties may continue to use old forms of security documents, but this will not have the effect of invoking the pre-PPSA system of priorities. The use of a chattel mortgage or conditional sales agreement will create a security interst, ${ }^{175}$ but the priority of the security interest will be governed by the PPSA. Where the parties continue to use a floating charge debenture there is some controversy over whether the priorities resulting from the application of the PPSA are any different from those that would have resulted had the secured party taken a general security agreement in all present and after acquired property. ${ }^{176}$

168. Supra n. 160, s. 12.

169. Id. s. 35.

170. Id. s. 34 .

171. Id. s. 30 .

172. Id. s. 31 .

173. Id. s. 20.

174. A limited exception is created by, id. s. 35(5), which gives a seizing creditor priority over a secured party to the extent that the secured party makes further advances with knowledge of the seizure.

175. Supra n. 162, s. 3(1)(b).

176. See J. S. Ziegel, "Recent and Prospective Developments in the Personal Property Security Law Area" (1985) 10 C.B.L.J. 131 at 146-54; J. S. Ziegel and R.C.C. Cuming, "The Modernization of Canadian Personal Property Security Law" (1981) 31 U.T.L.J. 249 at 26770; A. Abel, "Has Article 9 Scuttled the Floating Charge" in Aspects of Comparative Commercial Law (Ziegel and Foster eds.) (1969) Ch. 27; P. D. Maddaugh, "Security on Personal Property in the 1980s" L.S.U.C. Special Lectures 1982: Corporate Law in the 80s (1982) 349 at 357-62. 
The time of attachment of a floating charge was the first issue singled out for litigation. The parties to a security agreement may delay attachment if they wish, ${ }^{17}$ and it was contended that the use of a floating charge debenture manifested an intention that the security interest should not attach until an event of crystallization occurred. This argument was rejected. The use of the floating charge does not demonstrate an intention to delay attachment until crystallization, ${ }^{178}$ and the Alberta PPSA contains a legislative confirmation of this view. ${ }^{179}$

A more difficult issue is whether the use of a floating charge carries with it an implied subordination of the security interest. Under traditional law, both property concepts and agency concepts combined to create the matrix of rules that resolved priority competitions. The PPSA also contains an agency concept: where the collateral is dealt with, the security interest "continues in the collateral, unless the security party expressly or impliedly authorizes the dealing." 180 Furthermore, a secured party may, in a security agreement or otherwise, subordinate its security interest to a third party. ${ }^{181}$ Under traditional law, the implied authority extended to the granting of competing security interests on a portion of the assets, but did not include a mortgage of the entire undertaking. Ordinary course sales were also authorized, and a generous latitude was given to this notion..$^{182}$ The question is whether this implied authority carries over into the PPSA. If the parties expressly agree to a set of authorized dealings, effect will be given to this intention. Accordingly, if the debenture contains a permissive provision or subordination clause, a transaction falling within the express licence will be entitled to priority. ${ }^{183}$ Similarily, the presence of a restrictive provision will operate to narrow the scope of authorized activities. However, where the security agreement is silent, the courts must determine the scope of the implied licence. Professor Ziegel suggests that the Canadian cases concerning a fixed mortgage on a trader's inventory are a better guide than the jurisprudence on the debtor's dealing powers under a floating charge. ${ }^{184}$

177. Supra n. 162, s. 12(1).

178. Re Royal Bank of Canada and G.M. Homes Inc. (1982) 10 D.L.R. (4th) 439 (Sask. C.A.); Euroclean Canada Inc. v. Forest Glade Investments Ltd., supra n. 166.

179. Supra n. 162; s. 12(1) provides that a "security interest, including a security interest in the nature of a floating charge, attaches when" the three criteria in clauses (a), (b) and (c) are satisfied.

180. Id. s. $28(1)(\mathrm{a})$.

181. Id. s. 40.

182. Re H.H. Vivian \& Co. [1900] 2 Ch. 654 (sale of one of the branches of a business within its ordinary course of business).

183. Euroclean Canada Inc. v. Forest Glade Investments Ltd., supra n. 166; Acmetrack Ltd. v. Bank Canadian National, supra n. 109; J. S. Ziegel, "The Scope of Section 66a of the OPPSA and Effects of Subordination Clause: Euroclean Canada Inc. v. Forest Glade Investments Ltd." (1984) 9 C.B.L.J. 367 at 371-4. Compare the interpretation given to the covenant pattern in Sperry Inc. v. Canadian Imperial Bank of Commerce (1985) 17 D.L.R. (4th) 236 (Ont. C.A.) which did not amount to a subordination.

184. J.S. Ziegel, supra n. 176 at 153-4. 
There is also the matter of the translation of automatic crystallization provisions into a system of fixed security interests. Since the idea of a floating security interest is unknown, it seems most appropriate to reconceptualize automatic crystallization as simply a cessation of the debtor's authority to carry on in the ordinary course of its business as defined by the restrictive and permissive provisions contained in the security agreement (or in the absence of express provisions, as implied by the court). These provisions are fully effective as between the secured party and the debtor. ${ }^{185}$ The effect on third parties is more troublesome. Ordinary course buyers will continue to have priority unless they actually know that authority to deal with the goods has been withdrawn. But third parties who know that the transaction falls within the authorization given to the debtor, but do not know of the subsequent withdrawal of that authority, will lose out unless further agency principles are introduced into the priority system. If the third party is allowed to invoke the principle of apparent authority, then it will be entitled to priority if the transaction falls within the scope of the original licence and it is without knowledge of the termination of authority. ${ }^{186}$ Although it might be argued that the introduction of the principle of apparent authority will undermine the priority structure of the PPSA, ${ }^{187}$ the analysis is heavily dependent upon agency principles, and it would be artificial to admit some but not others. If the secured party knows of the cessation of the debtor's authority but permits the debtor to continue nonetheless, the natural conclusion to be drawn is that the secured party has reinstated the debtor's actual authority. The line between apparent authority and actual authority will often be indistinct, and yet this determination will be of crucial significance. The introduction of an apparent authority principle would reduce the importance of this distinction.

The PPSA does not explicitly regulate priorities between a security interest and a statutory lien or deemed trust. ${ }^{188}$ Such disputes were formerly resolved by a property approach: the statutory lien or deemed trust had priority if it came into existence before crystallization. ${ }^{189}$ If a property approach were taken under the PPSA, the secured party would always be entitled to priority since the security interest would immediately attach to

185. Section 9 of the PPSA, supra n. 162, provides that a security agreement is effective in accordance with its terms.

186. See, R.M. Goode, supra, n. 14 at 90 (debtor clothed with apparent authority allows a subsequent purchaser to claim that it was unaware of the termination of the debtor's authority to manage his assets with the result that the purchaser is not bound by it).

187. Several interpretative arguments can be made. For example, s. 64(5) of the Saskatchewan PPSA, supra n. 160, provides that the "principles of the common law, equity and the law merchant, except insofar as they are inconsistent with the express provisions of this Act, supplement this Act and continue to apply." It may therefore be argued that the principle of apparent authority should apply. It might, however, be argued that since s. 40 of the Alberta PPSA provides that a subordination is effective according to its terms and s. 28(1)(a) provides that the security interest "continues in the collateral, unless the secured party expressly or impliedly authorized the dealing", this should be regarded as an exhaustive enumeration of agency principles in the PPSA.

188. Supra n. 162, s. 4(a).

189. Supra n. 140. 
the debtor's assets, whereas the statutory lien or trust would only arise at some future time. Courts in PPSA jurisdictions have in fact shifted from a property analysis. ${ }^{190} \mathrm{In}$ its place, an implied authority analysis is employed. In the case of payroll deductions, the secured party has authorized the payment of wages to employees. The money once paid as wages ceases to be the property of the employer and the secured party does not have a security interest in the holdback. But in most cases the money is not kept separate and apart. The deemed trust provision operates as a relaxation of the equitable tracing rules and allows the claimant to trace the trust funds into the general assets of the debtor with priority over a secured party.

There is, however, recent evidence to suggest that the concept of the floating charge has retained some hold on the judicial mind. A recent example may be found in Armstrong v. Coopers \& Lybrand Ltd. ${ }^{191}$ The competition was between a section 178 Bank Act security and a deemed statutory trust. The section 178 security, which traditionally has been regarded as a fixed security interest, was held to be a floating charge. It would be more sensible to view the section 178 security interest as a fixed interest, but to grant priority to the deemed statutory trust on the basis of trust law principles. Better still, the statutory provisions creating liens and deemed trusts should be redrafted so as to expressly state in PPSA vocabulary the priority status that it enjoys against a secured party. ${ }^{192}$

\section{THE FLOATING CHARGE AS A FRAUDULENT PREFERENCE}

Fraudulent preference law is integrally connected with a system of insolvency law which transforms the basic norm of individual collection to one of collective action. ${ }^{193}$ In the absence of a system of insolvency law, each unpaid creditor must individually extract value from the debtor, whether through state-assisted coercion (the judgment enforcement system) or private persuasion (the voluntary transfer of money or other assets). There is no duty to consider the interests of competing creditors and a theory of fraudulent preference is inappropriate. But once a system of collective debt enforcement is introduced, these assumptions must be changed. The rule of "first come, first served" is replaced with a rule of pari passu sharing among the general body of unsecured creditors. ${ }^{194}$

190. Re Royal Bank of Canada and G.M. Homes Inc., supra n. 178. Compare the strict property approach which led to the opposite result in Re Stephen's Welding Ltd. (1980) 116 D.L.R. (3d) 543 (Alta. Q.B.).

191. (1986) 53 O.R. (2d) 468 (H.C.J.), affd. (1988) 61 O.R. (2d) 129 (C.A.).

192. See, for example, the Labour Standards Act, R.S.S. 1978, c. L-1, s. 56 as am. S.S. 1980-81, c. 63, s. 5; The Landlord and Tenant Act, R.S.S. 1978, c. L-6, s. 25 as am. S.S. 1979-80, s. 28, ss. 3 and 4 . See also the amendments to Alberta statutory lien provisions consequential upon the enactment of the PPSA, supra n. 162, for example, s. 80 of the PPSA amends s. 113 of the Employment Standards Code, supra n. 137.

193. Although preference law depends upon the existence of bankruptcy legislation, it was originally decisional in source. See R. Weisberg, "Commercial Morality, the Merchant Character, and the History of the Voidable Preference" (1986) 39 Stan. L. Rev. 3 at 39-55.

194. The creditor's relief legislation (such as that contained in the Executions Act, R.S.A. 1980, c. E-14) implements a system of pari passu sharing among execution creditors, but the overall character of the enforcement system remains one of "first strike, first right". 
During this transition there is a danger that some creditors, in anticipation of an impending insolvency, will attempt a last-minute grab for assets and thereby frustrate the underlying policy of insolvency law. ${ }^{195}$ Fraudulent preference law is designed to inhibit these eleventh-hour grabs. ${ }^{196}$

Canadian courts have never been troubled with cases in which an insolvent debtor has been persuaded to grant a security interest to a creditor to secure a pre-existing unsecured debt. These crude attempts have regularly been set aside as fraudulent preferences. ${ }^{197} \mathrm{~A}$ more subtle form of preference is associated with the use of after-acquired property provisions in security agreements. The controversial cases are those in which the security agreement was executed at a time when the debtor was solvent and the security interest automatically attaches to new property during a subsequent period during which the debtor has become insolvent. The courts have held that the security interest thereby obtained in the new collateral will not be presumed to be preferential. ${ }^{198} \mathrm{~A}$ theory of retrospective attachment is used in support of this outcome. ${ }^{199}$ The grant of security is said to create an inchoate security interest that attaches at the date of the security agreement. The security interest in after-acquired property is deemed to have come into existence at the time the security agreement was executed. This brings the transfer outside of the suspect period.

The troublesome feature of this principle is that it insulates the secured transaction despite debtor misbehavior. In its most obnoxious form, the misbehavior takes the form of a calculated decision to run up excessive amounts of unsecured credit in order to pay off an undersecured financier. This scenario was described by a representative of the Canadian Cattlemen's Association: ${ }^{200}$

[W] hen a packing company gets into difficulty with the cash flow, it starts buying up more cattle. In fact, this has occurred so often in the past that we now interpret it as a danger signal, when the packer begins gathering about himself large supplies of cattle. It is a signal that he is in trouble, because he knows - or he knew before the law was changed in the United States - that when he goes into receivership or bankruptcy those cattle procured but not paid for will bail him out with the bank and the producer will be left empty-handed.

The debtor may wish to "feed the floating charge" at the expense of the trade creditors in order to limit the exposure of a principal shareholder under a guarantee, or to put the debtor in good stead with the financer following the insolvency.

195. See T.H. Jackson, The Logic and Limits of Bankruptcy Law (1986) at 122-6.

196. See generally, J.J. Morrison, "The Impact of Bankruptcy Preference Rules on Commercial Secured Financing in the United States and Canada" in Debtor-Creditor Law-Practice and Doctrine. (Springman and Gertner eds.) (1985) 551.

197. Canadian Imperial Bank of Commerce v. Grande Cache Motor Inn Ltd. (1978) 4 Alta. L.R. (2d) 319 (T.D.); Burlingham v. Evjens Carpet Ltd. (1983) 49 C.B.R. (N.S.) 220 (Sask. Q.B.).

198. Re Lind [1915] 2 Ch. 345.

199. See R.M. Goode, "Is the Law Too Favourable to Secured Creditors" (1983-84) 8 C.B.L.J. 53 at 61-3.

200. Proceedings of the Standing Senate Committee on Banking, Trade and Commerce (1978-79), 30th Parl., 4th Sess., at 19:17. 
With the advent of the PPSA, it seems that this sort of conduct will come under judicial scrutiny. There is no counterpart to retrospective attachment. The security interest attaches when the debtor acquires rights in the collateral. ${ }^{201}$ This does not mean that the security interest in new assets acquired during the suspect period will always be set aside as a fraudulent preference. The fact that it attached in accordance with a pre-existing agreement should be sufficient to rebut the presumption of preference. ${ }^{202}$ But if the avoiding creditor can further demonstrate that the debtor engaged in atypical conduct intended to benefit the secured creditor, then the transaction should be set aside.

A unique response to this problem is legislated in respect of the section 178 Bank Act security. A grower or producer of products of agriculture is given priority over the bank's security interest if the grower's or producer's claim arose within six months prior to bankruptcy ${ }^{203}$ Of course, this goes well beyond an attempt to deal with increases in the bank's security margin attributable to manipulative behavior. Perhaps it can be viewed as a presumptive rule that all acquisitions of new assets are preferential. The presumption is made irrebuttable so as to achieve an overbroad but certain rule. ${ }^{204}$ However, the fit between the policy against manipulative conduct and the actual operation of the rule is so crude that one strongly suspects that its main goal was to rebalance the distribution of assets between secured and a select group of unsecured creditors. ${ }^{205}$

\section{CONCLUSION}

When the judiciary accepted the idea of a security interest that attached automatically to after-acquired property, they also accepted the responsibility for creating a matrix of priority resolving principles that would goven this new device. In doing so, the courts have given expression to two concerns. The first is with the effect on unsecured creditors. So long as a security interest was restricted to present assets, or even to fixed assets, there existed, in most cases, a class of unencumbered assets against which employees and general creditors could have recourse. The invention of the floating charge dramatically altered this equilibrium, as it amounted to a "sweeping away" of all assets. Creditors thereafter would obtain priority only if they completed execution before the floating charge crystallized.

201. Supra n. 162, s. 12(1).

202. Re Jackson \& Bassford, Limited [1906] $2 \mathrm{Ch} .467$ at 477; Re D. Elkind Clothing Inc. (1978) 26 C.B.R. (N.S.) 240 (Ont. S.C.).

203. Bank Act, R.S.C. 1985, c. B-1, s. 178(6),(7).

204. D. Kennedy, "Form and Substance in Private Law Adjudication" (1976) 89 Harv. L. Rev. 1685 at $1687-701$.

205. A similar controversy has arisen in the United States regarding the avoiding power under section 547 of the Bankruptcy Code. A two-point net improvement test is adopted under which any increase in value of the assets during the 90 day period immediately preceeding bankruptcy will be presumed to be preferential. It is unclear whether the original concern was with deliberate manipulative behavior, or whether it was a response to wider distributional concerns. See S.L. Harris "A Reply to Theodore Eisenberg's 'Bankruptcy Law in Perspective"" (1982) 30 U.C.L.A. L. Rev. 327 at 335-57; and T. Eisenberg, "Bankruptcy Law in Perspective: A Rejoinder" (1983) 30 U.C.L.A. L. Rev. 617 at 631-2. 
This factor has never played a dominant role in the judicial construction of a system of priorities. In England, a limited legislative intervention dissuaded the courts from imposing any further restrictive rules. Some Canadian courts have been more receptive, and have in consequence rejected the idea of a fixed charge coupled with a licence as well as the idea of automatic crystallization of a floating charge. Nevertheless, this response is largely ineffectual. The vast body of general creditors will remain subordinate to a floating charge.

The dominant consideration in England has rather been with the situational monopoly that is generated when a first in time priority rule is combined with the recognition of a security interest in after-acquired property. English courts have consistently adopted rules which permit a company to obtain new credit on the security of a limited class of assets in priority to the floating charge. Although early Canadian law relied heavily on the English jurisprudence, Canadian law is now rapidly discarding the English view. The Canadian version of the floating charge is taking on the character of a fixed security interest subject to a first to register rule. This Canadian development may be attributable to the early availability of the wholesale conditional sales agreement as an institutional security device, and as well may be influenced by the greater judicial familiarity with the priority system contained in modern personal property security legislation in other provinces.

The enactment of personal property security legislation greatly accelerates these two trends. The concept of crystallization is eliminated. A perfected security interest is entitled to priority over virtually all creditors, including execution creditors who complete the execution process before the secured party intervenes. The priority of the security interest is governed by a first to register priority rule subject to a special priority in favour of purchase-money security interests.

Although the PPSA adequately deals with the perceived problem of the situational monopoly, the priority position of an all-encompassing security interest relative to unsecured creditors remains problematic. Future initiatives will likely proceed along two lines. The first is the distributional issue. The Cork Committee in England recommended that a fund equal to $10 \%$ of the net realization of assets subject to a floating charge should be made available for distribution among unsecured creditors. ${ }^{206}$ Other reforms might include a return to legal restrictions upon the types of assets that can be encumbered. Such proposals are vulnerable to the criticism that unsecured creditors are perfectly capable of responding to the increased risk on insolvency by increasing the cost of credit, and that these legal initiatives may in fact make the assessment of their bankruptcy entitlements more difficult. ${ }^{207} \mathrm{~A}$ more viable approach may be to isolate those

206. Insolvency Law and Practice (Report of the Committee, Chairman Sir Kenneth Cork, (cmnd. 8558, 1982), at 347-51.

207. F.H. Buckley, supra n. 59 at 1421-6. 
classes of creditors for whom it is unrealistic to expect such behavior. Employees, pre-paying consumer buyers and tort claimants might be given a super-priority. This is the present direction of law reform measures, ${ }^{208}$ but amendment to bankruptcy legislation is required to ensure that this priority persists in bankruptcy. ${ }^{209}$

The second form of initiative is based upon monitoring considerations and the unfairness of awarding everything to a "secured party who stands idly by while a doomed enterprise goes down the slippery slope into bankruptcy."210 Likely this will take the form of a further judicial or legislative development of the fraudulent preference idea. At very least, extraordinary transactions that fatten the corpus of business assets prior to insolvency ought to be struck down.

208. See, for example, the Employment Standards Code, supra n. 139, s. 110 (super-priority given to employees for unpaid wages); Law Reform Commission of British Columbia, Report on the Buyer's Lien: A New Consumer Remedy (1987) L.R.C. 93. See also "Tort Creditor Priority in the Secured Credit System: Asbestos Times, the Worst of Times" (1984) 36 Stan. L. Rev. 1045 (proposed super-priority for tort claimants).

209. See the discussion, supra in Part V, F, of this article.

210. G. Gilmore, "The Good Faith Purchase Idea and the Uniform Commercial Code: Confessions of a Repentant Draftsman" (1981) 15 Georgia L. Rev. 605 at 627. 